Arkivoc

Free to Authors and Readers
A Platinum Open Access Journal for Organic Chemistry
Paper

Arkivoc 2021, part iii, 138-156

\title{
Aminomethylpyridinequinones as new ligands for PEPPSI-type complexes
}

\section{Roman Gajda, ${ }^{\text {a }}$ Albert Poater, ${ }^{\mathrm{b}}$ Artur Brotons-Rufes, ${ }^{\mathrm{b}}$ Sebastian Planer, ${ }^{\text {a }}$ Krzysztof Woźniak, $^{\mathrm{a}} \mathrm{Karol} \mathrm{Grela},{ }^{\mathrm{a}}$ and Anna Kajetanowicz ${ }^{\mathrm{a}, \mathrm{c}, *}$}

${ }^{a}$ Biological and Chemical Research Centre, Faculty of Chemistry, University of Warsaw, Żwirki i Wigury 101, 02-089 Warsaw, Poland

${ }^{b}$ Institut de Química Computacional i Catàlisi, Departament de Química, University of Girona, c/ Maria Aurèlia Capmany 69, Girona 17003, Catalonia, Spain

c Institute of Organic Chemistry, Polish Academy of Sciences, Kasprzaka 44/52, 01-224 Warsaw, Poland Email: a.kajetanowicz@uw.edu.pl

\section{Dedicated to Professor Lanny Liebeskind}

\section{Received 12-15-2020}

Accepted 01-27-2021

Published on line $02-10-2021$

\section{Abstract}

A set of six new catalysts possessing quinone moieties in a pyridine ligand was synthesized and fully characterized by standard analytical techniques, including X-Ray crystallography. The results obtained in Suzuki and Mizoroki-Heck cross-coupling reactions catalyzed by quinone-based compounds were comparable to these obtained in the presence of the original PEPPSI complex designed by Organ. DFT calculations allow to see the structural and electronic factors to describe their similarity. On the other hand, steric maps and $\mathrm{NCl}$ plots were the tools to have a more global view of the systems studied, leaving the sphere of reactivity around the metal.

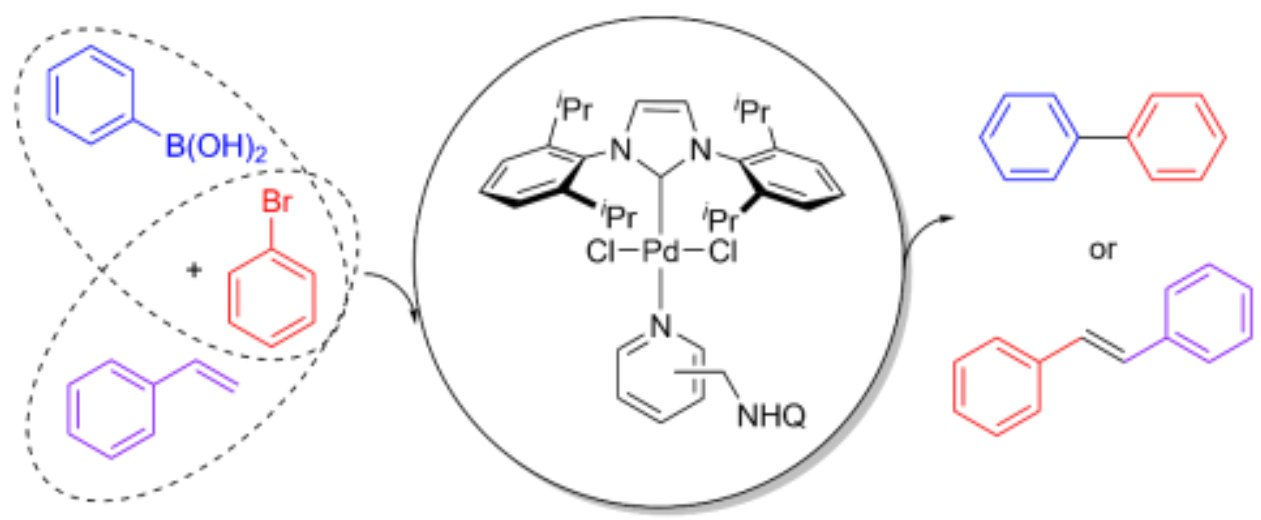

Keywords: Cross-coupling, PEPPSI, pyridine, quinones, NHC 


\section{Introduction}

Palladium-catalyzed cross-coupling reactions are one of the most popular methodologies in the formation of carbon-carbon, carbon-nitrogen, carbon-oxygen, and carbon-sulfur bonds ${ }^{1,2}$ widely utilized not only in academic research, but also in the pharmaceutical industry (Figure 1). ${ }^{3}$ They are typically performed under mild reaction conditions, which minimize the formation of unwanted side products and, consequently, provide the desired compounds with high selectivity. What is more, $\mathrm{Pd}$ catalysis shows tolerance towards a plethora of functional groups on both coupling partners. Both ligand-free complexes, which are inexpensive but at the same time quite susceptible to deactivation due to precipitation of palladium black in the course of the reaction, and complexes in which palladium is sheltered by different classes of ligands such as, inter alia, phosphines and pincer-type as well as NHCs (N-heterocyclic carbenes), can be used as catalysts.

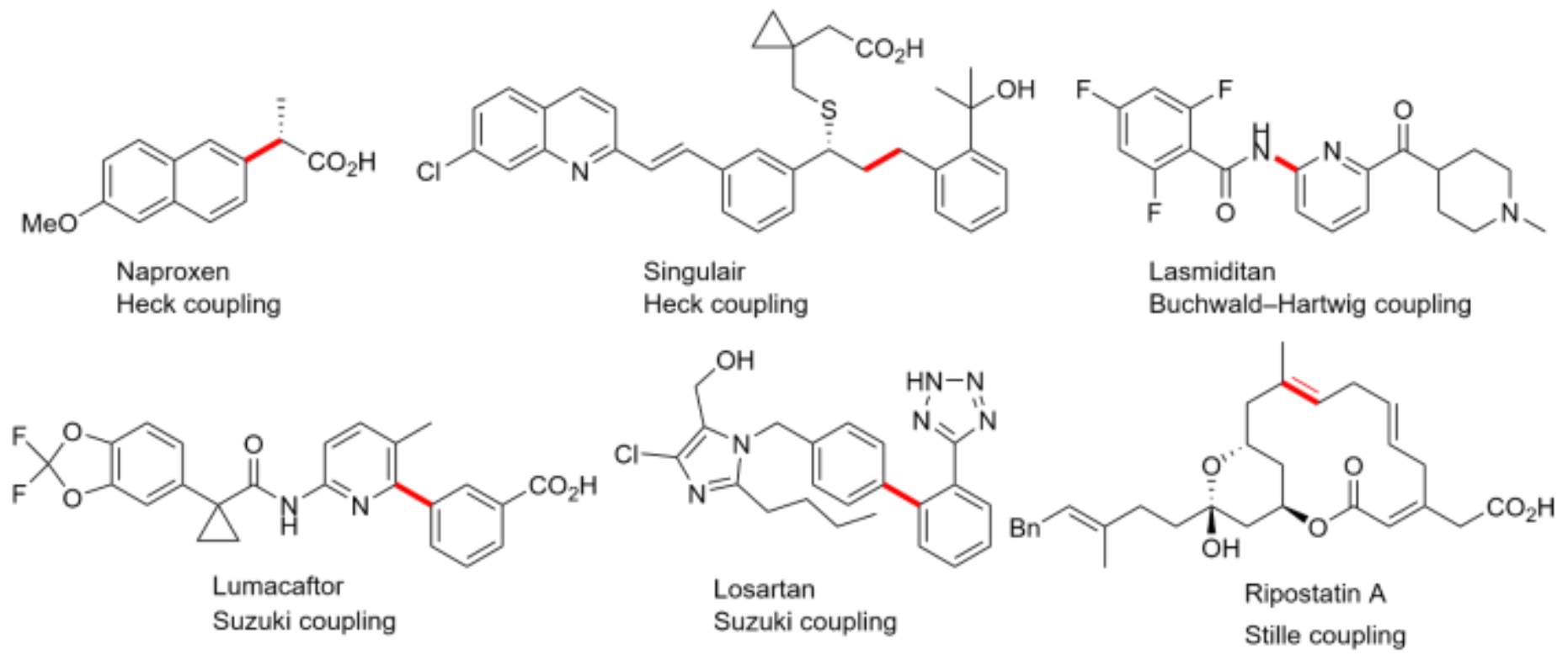

Figure 1. Examples of approved drugs and drug candidates where palladium-catalyzed cross-coupling reactions are employed to form critical carbon-carbon bonds.

One of the most important classes of complexes containing NHC ligands are the PEPPSI-type (Pyridine-Enhanced Precatalyst Preparation Stabilization and Initiation) catalysts developed by Organ (Figure 2).4-6 The parent complex was obtained from the reaction between $\mathrm{PdCl}_{2}$, a bulky $\mathrm{NHC}$ (2,6-diisopropylphenylimidazolium chloride-IPr), and 3-chloropyridine under atmospheric conditions. It is not only exceptionally stable outside an inert atmosphere but also can be treated as a universal catalyst for the majority of cross-coupling reactions ${ }^{7,8}$ including Suzuki-Miyaura coupling of esters ${ }^{9}$ or amides ${ }^{10}$ (by C-O or C-N cleavage). 

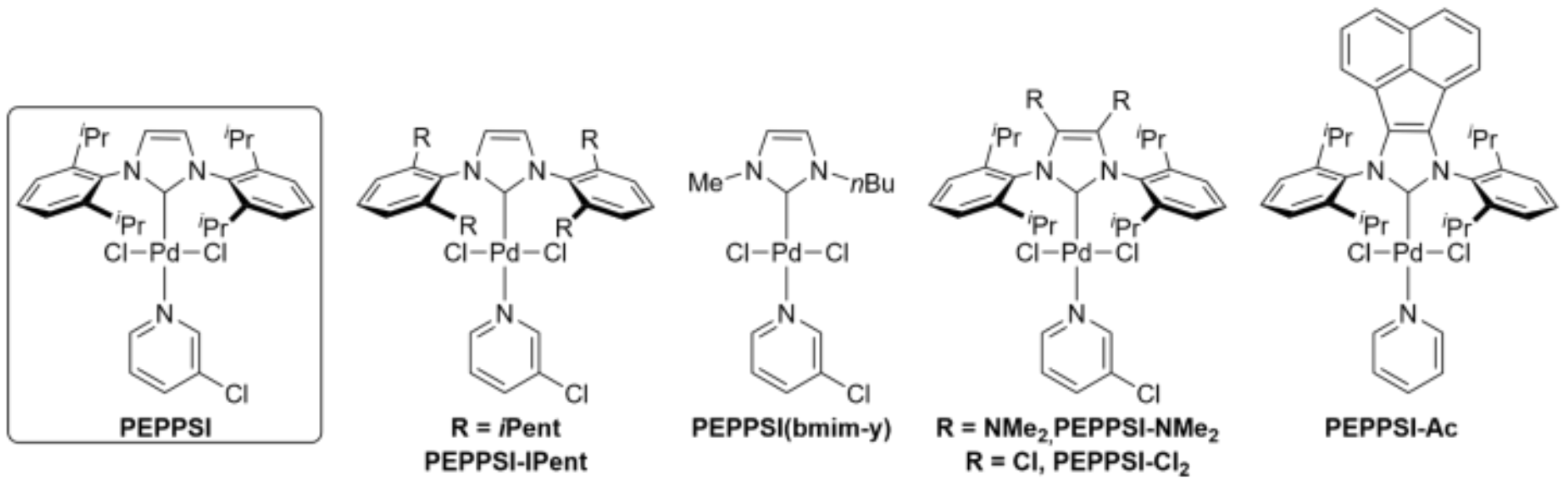

Figure 2. Known examples of PEPPSI-type complexes.

Since the introduction of this catalyst to the organic chemist's toolbox, Organ and others have been working on its structural modifications to reach even higher activity and selectivity in difficult coupling reactions (Figure 2). First, more bulky aryl substituents, like, e.g., 2,6-diisopentylphenyl, were utilized. The resulting PEPPSI-IPent complex proved to be an excellent catalyst, for example, in reactions of sterically hindered aryl halides with aryl boronic acids. ${ }^{11}$ The opposite approach was employed by Trzeciak et al. who successfully applied PEPPSI-type complexes containing (1-butyl-3-methylimidazole-2-ylidene) NHC ligand in Suzuki-Miyaura and Hiyama coupling reactions (PEPPSI(bmim-y), Figure 2). ${ }^{12}$ In further modifications, additional substituents on the backbone of the imidazole ring were introduced. For example, César and Lavigne introduced amine substituents (PEPPSI-NMe2, Figure 2), which exerted a major doping effect on the catalytic performance allowing for both a significant decrease of the catalyst loading and the development of extended applications to challenging reaction partners in Buchwald-Hartwig amination. ${ }^{13}$ Also, introduction of chlorine substituents has had a significant influence on catalyst activity and selectivity, especially in Negishi cross-couplings between alkylzincs

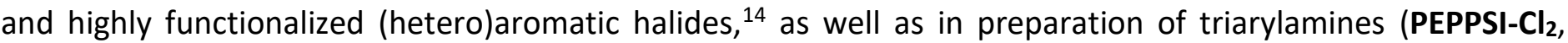
Figure 2). ${ }^{15}$ Further extension of the imidazolium ring with the acenaphtho-substituent together with modifications of the aryl moieties allowed Verma ${ }^{16}$ and Liu $^{17}$ to effectively direct arylation of heteroarenes (PEPPSI-Ac, Figure 2). Similar activity was achieved when PEPPSI-themed palladium-NHC complexes based on benzimidazolium unsymmetrical N-heterocyclic carbenes were used. ${ }^{18}$ Replacement of NHC with 1,2,3-triazolin5-yliden-type ligand was another successful structural modification, developed by Pietraszuk et al. ${ }^{19}$

The pyridine ligand has been less frequently modified. In the original PEPPSI catalyst, the electron-withdrawing chlorine substituent at the 3-position facilitated the dissociation of this ligand and consequently activation of the catalyst. Further modification relies mostly on the introduction of steric bulkiness, which in some cases can facilitate the initial reductive elimination step to generate $\mathrm{Pd}^{0}$ and thus enable the catalytic cycle. ${ }^{5}$

In order to increase the chemical diversity, in the current work, we decided to introduce more advanced substituents-quinone groups, which were previously proved to interact with $\mathrm{Pd}^{20,21}$-into the structure of the pyridine ligand. Such complexes should not only be interesting from a structural point of view, but also can give interesting interactions between the metallic center and quinone moiety. This design was in some part inspired by the advantageous role of quinone co-ligands noted in catalytic olefin metathesis ${ }^{22}$ and in Pd-catalyzed oxidative $\mathrm{C}-\mathrm{H}$ arylation. ${ }^{20}$ The precursor to produce the target functionalized derivative PEPPSI based catalysts was air-stable NHC-Pd(II) chloro-dimer, $[\mathrm{Pd}(\mathrm{NHC})(\mu-\mathrm{Cl}) \mathrm{Cl}]_{2},{ }^{23,24}$ for the development of more reactive, general, easily accessible, and readily available $\mathrm{Pd}(\mathrm{II})-\mathrm{NHC}$ pre-catalysts in cross-coupling reactions. ${ }^{25-29}$ 


\section{Results and Discussion}

\section{Ligands and complexes preparation}

To have access to pyridine ligands with a quinone moiety, a modified literature procedure was applied..$^{30,31}$ The reaction of 2,3-dichloro-5,6-dimethyl-1,4-benzoquinone (1a) or 2,3-dichloro-1,4-naphthoquinone (1b) with the three isomeric aminomethylpyridines (2a-c, 2-, 3- and 4-(aminomethyl)pyridines) in ethanol providing the desired 2-substituted-1,4-quinone derivatives $\mathbf{3}$ in moderate yields (Scheme 1). Interestingly, in a previous study, compounds $\mathbf{3 d}$ and $\mathbf{3} \mathbf{f}$ were found to possess extremely potent activity against S. aureus and B. subtilis. ${ }^{30}$ 3d was also used as a chemosensor for metal ions. ${ }^{32,33}$<smiles>O=C1C(Cl)=C(Cl)C(=O)c2ccccc21</smiles>

$1 a, b$<smiles>NCc1ccccn1</smiles>

2a-c

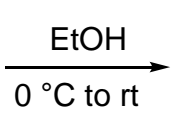<smiles>O=C1C(Cl)=C(NCc2ccccn2)C(=O)c2ccccc21</smiles><smiles>CC1=C(C)C(=O)C(NCc2ccccn2)=C(Cl)C1=O</smiles>

3 a, $2-, 47 \%$

3 b, 3, $49 \%$

3c, $4-, 45 \%$<smiles>O=C1C(Cl)=C(NCc2ccccn2)C(=O)c2ccccc21</smiles>

3d, $2-, 56 \%$

3 e, $3-, 50 \%$ 3f, $4-, 34 \%$

Scheme 1. Synthesis of pyridine ligands.

With the new pyridine ligands in hand, we performed the synthesis of PEPPSI type complexes (Scheme 2). First, the palladium dimer 6 was synthesized using two-step procedure starting from the commercially available 1,3bis(2,6-diisopropylphenyl)imidazolium chloride (4). Next, the NHC carbene from copper complex $\mathbf{5}$, obtained by the reaction of $\mathbf{4}$ with copper(I) oxide in boiling acetone, was transmetallated to palladium in the presence of $\mathrm{PdCl}_{2}(\mathrm{PhCN})_{2}$. The same compound 6 can be obtained in a one-step procedure as presented recently by Nolan and Szostak. ${ }^{24}$ The complex 6 thus obtained was then utilized in reactions with the previously synthesized pyridine ligands 3a-f to provide the desired catalysts $7 a-f$ in good and very good yields, up to $96 \%$. 

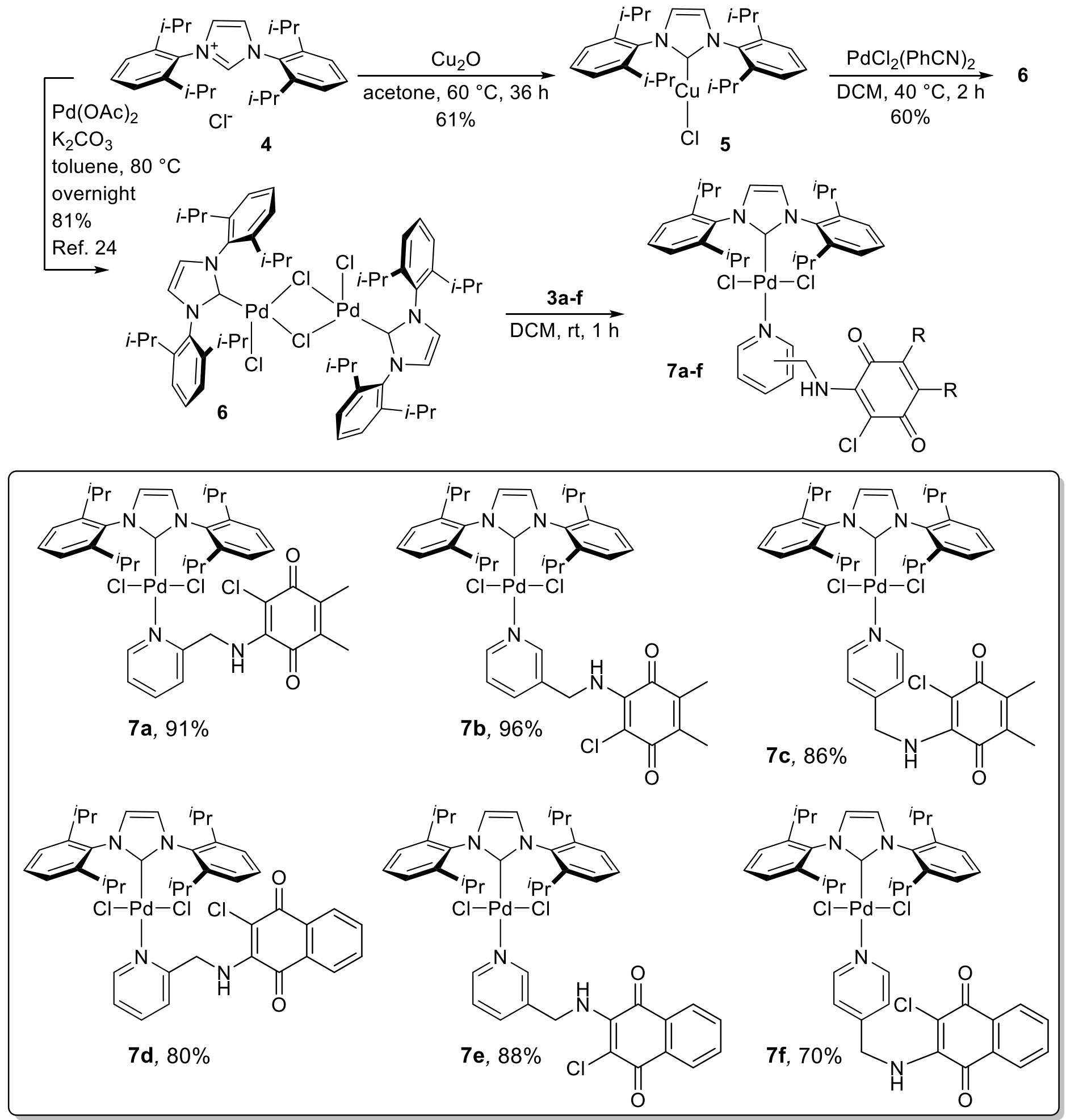

Scheme 2. Synthesis of PEPPSI type complexes 7a-f.

\section{Structure analysis}

With the use of X-ray measurements, the crystallographic structures of all six PEPPSI complexes, 7a-f, have been determined (Figure 3). Measurements were conducted at $100 \mathrm{~K}$ on diffractometers equipped either with molybdenum or copper X-ray source (for samples showing weaker diffraction pattern copper X-ray source was chosen). The structural data were deposited at the CCDC with deposition numbers 2046352-2046354, 2046370, 
2048054 and 2050163. Most of these structures contain molecules of the solvent, dichloromethane, which are built-in. Both complexes with ligands at the 2-position (7a and 7d) crystallize in a tetragonal crystal system, space group 141/a, with 16 molecules in the unit cell. It may suggests that for some reason, in these particular types of complexes, the 2-position causes such a molecular arrangement that tetragonal symmetry is preferred. However, in this context also the phenomenon of disorder might be important. Also strongly disordered molecules of $7 e$ crystallized in this space group (141/a). In the case of $7 a$ positional disorder of the ligand is observed, whereas in $7 e$ also benzene rings substituted with isopropyl groups are significantly disordered. In the case of the complex with 3- substituted ligand (7b), the crystal system is monoclinic, space group Pc. There are four molecules in the unit cell, two in the asymmetric unit. Mutual orientation of the molecules of the complex suggests that there might be a center of symmetry between them, but apparently the presence of the solvent molecules has a disturbing effect and the structure was finally solved and refined as a noncentrosymmetric Pc. In the case of the complexes with the 4-substituted ligand (7c and 7f), the crystal system is monoclinic, space group $\mathrm{P} 2_{1} / \mathrm{n}$ and $\mathrm{P} 2_{1} / \mathrm{c}$, respectively. In the case of $7 \mathrm{c}$, a significant positional disorder is also observed, but in this case it concerns only one of the benzene rings with two isopropyl substituents.

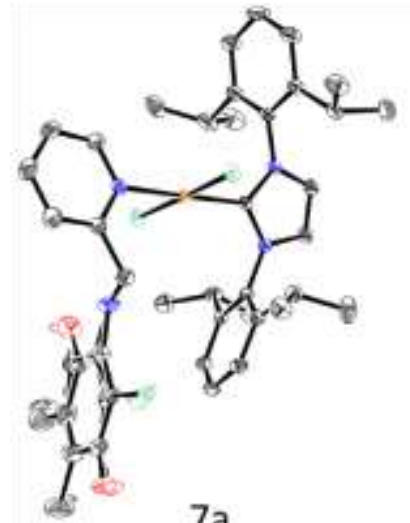

$7 a$

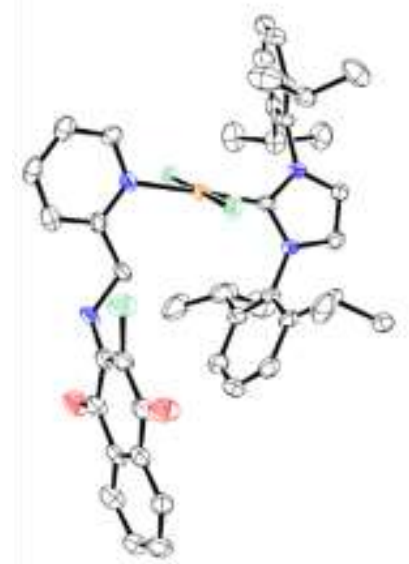

$7 d$

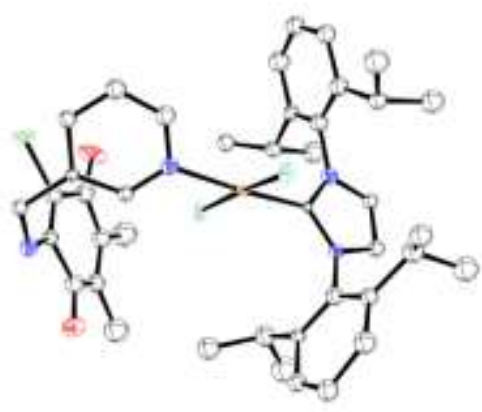

$7 b$

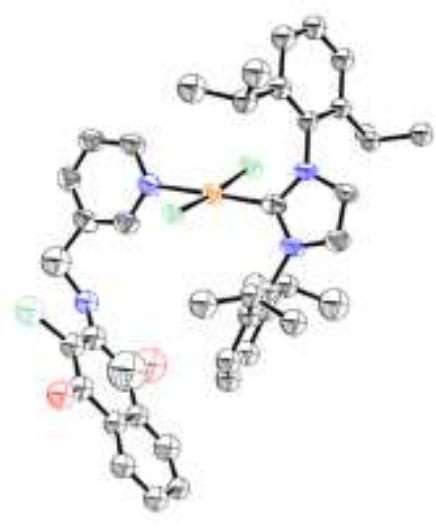

$7 \mathrm{e}$

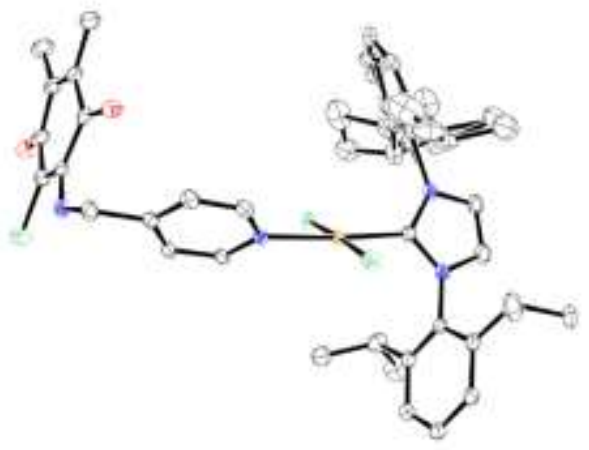

$7 c$

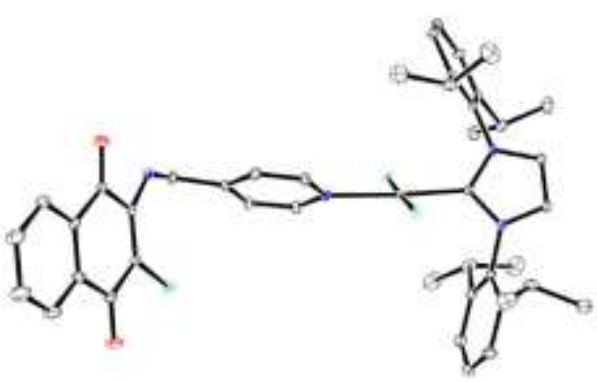

$7 f$

Figure 3. X-ray crystal structures of the new catalysts with $50 \%$ probability ellipsoids (40\% for $7 \mathbf{b}$, for clarity of the picture). Hydrogen atoms, disordered atoms and solvent molecules have been also omitted for clarity.

\section{Catalytic activity studies}

The activity of the new complexes was checked in standard cross-coupling reactions, namely, Suzuki and Mizoroki-Heck processes. 


\section{Suzuki reaction}

First, the Suzuki reaction between phenylboronic acid (8a) and 3,5-dimethoxybromobenzene (9a) catalyzed by $\mathbf{7 d}$ was performed. The composition of the reaction mixture was analyzed by gas chromatography using durene (1,2,4,5-tetramethylbenzene) as an internal standard. Initially, we focused on the selection of appropriate base $\left(\mathrm{K}_{2} \mathrm{CO}_{3}, \mathrm{Cs}_{2} \mathrm{CO}_{3}, \mathrm{Ag}_{2} \mathrm{CO}_{3}, \mathrm{CH}_{3} \mathrm{COOK}, \mathrm{K}_{3} \mathrm{PO}_{4}\right)$ and solvent (DMF, 1,4-dioxane, THF). The results are presented in Scheme 3 and in Table 1 (entries 1-15).
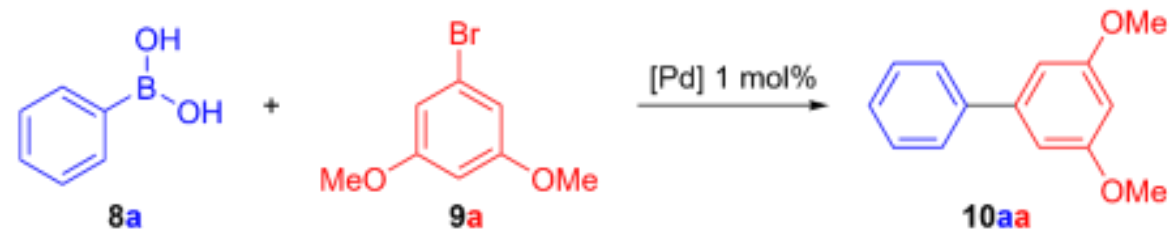

Scheme 3. Suzuki reaction catalyzed by PEPPSI-type complexes.

Table 1. Suzuki reaction between $\mathbf{8 a}$ and $9 \mathrm{9}$ catalyzed by PEPPSI-type complexes

\begin{tabular}{|c|c|c|c|c|c|c|c|}
\hline Entry & Catalyst & Solvent & Base & Temp. $\left[{ }^{\circ}\right]$ & Time $[\mathrm{h}]$ & Conv. [\%] & Sel. [\%] \\
\hline 1 & $7 d$ & DMF & $\mathrm{K}_{2} \mathrm{CO}_{3}$ & 80 & 5 & 38 & 58 \\
\hline 2 & $7 d$ & DMF & $\mathrm{Cs}_{2} \mathrm{CO}_{3}$ & 80 & 5 & 32 & 80 \\
\hline 3 & $7 d$ & DMF & $\mathrm{Ag}_{2} \mathrm{CO}_{3}$ & 80 & 5 & 30 & 18 \\
\hline 4 & $7 d$ & DMF & $\mathrm{CH}_{3} \mathrm{COOK}$ & 80 & 5 & 30 & 49 \\
\hline 5 & $7 d$ & DMF & $\mathrm{K}_{3} \mathrm{PO}_{4}$ & 80 & 5 & 30 & 75 \\
\hline 6 & $7 d$ & 1,4-dioxane & $\mathrm{K}_{2} \mathrm{CO}_{3}$ & 80 & 5 & 16 & 60 \\
\hline 7 & $7 d$ & 1,4-dioxane & $\mathrm{Cs}_{2} \mathrm{CO}_{3}$ & 80 & 5 & 5 & 31 \\
\hline 8 & $7 d$ & 1,4-dioxane & $\mathrm{Ag}_{2} \mathrm{CO}_{3}$ & 80 & 5 & 10 & 20 \\
\hline 9 & $7 d$ & 1,4-dioxane & $\mathrm{CH}_{3} \mathrm{COOK}$ & 80 & 5 & 14 & 48 \\
\hline 10 & $7 d$ & 1,4-dioxane & $\mathrm{K}_{3} \mathrm{PO}_{4}$ & 80 & 5 & 5 & 35 \\
\hline 11 & $7 d$ & THF & $\mathrm{K}_{2} \mathrm{CO}_{3}$ & 60 & 5 & 5 & 70 \\
\hline 12 & $7 d$ & THF & $\mathrm{Cs}_{2} \mathrm{CO}_{3}$ & 60 & 5 & 10 & 80 \\
\hline 13 & $7 d$ & THF & $\mathrm{Ag}_{2} \mathrm{CO}_{3}$ & 60 & 5 & 12 & 17 \\
\hline 14 & $7 d$ & THF & $\mathrm{CH}_{3} \mathrm{COOK}$ & 60 & 5 & 2 & 46 \\
\hline 15 & $7 d$ & THF & $\mathrm{K}_{3} \mathrm{PO}_{4}$ & 60 & 5 & 3 & 80 \\
\hline 16 & $7 a$ & DMF & $\mathrm{K}_{3} \mathrm{PO}_{4}$ & 80 & 22 & 20 & 80 \\
\hline 17 & $7 b$ & DMF & $\mathrm{K}_{3} \mathrm{PO}_{4}$ & 80 & 22 & 50 & 90 \\
\hline 18 & $7 c$ & DMF & $\mathrm{K}_{3} \mathrm{PO}_{4}$ & 80 & 22 & 26 & 79 \\
\hline 19 & $7 d$ & DMF & $\mathrm{K}_{3} \mathrm{PO}_{4}$ & 80 & 22 & 35 & 87 \\
\hline 20 & $7 e$ & DMF & $\mathrm{K}_{3} \mathrm{PO}_{4}$ & 80 & 22 & 47 & 83 \\
\hline 21 & $7 f$ & DMF & $\mathrm{K}_{3} \mathrm{PO}_{4}$ & 80 & 22 & 40 & 85 \\
\hline 22 & PEPPSI & DMF & $\mathrm{K}_{3} \mathrm{PO}_{4}$ & 80 & 22 & 65 & 92 \\
\hline 23 & PEPPSI-Py & DMF & $\mathrm{K}_{3} \mathrm{PO}_{4}$ & 80 & 22 & 69 & 91 \\
\hline
\end{tabular}

Conditions: 1 mol\% of PEPPSI-type catalyst. Conversion and selectivity were determined based on GC measurements with durene as an internal standard. 
The coupling reaction between $8 \mathrm{a}$ and $9 \mathrm{a}$ worked best in DMF, the results were almost twice as good as in THF or 1,4-dioxane. From base typically used in Suzuki reactions, $\mathrm{Cs}_{2} \mathrm{CO}_{3}$ and $\mathrm{K}_{3} \mathrm{PO}_{4}$ in all solvents but 1,4-dioxane also gave the highest selectivity. Due to the lower cost of the latter, it was used in subsequent work, in which the activity of all PEPPSI-type complexes was compared (Table 1, entries 16-23). In the family of complexes possessing the quinone moiety, the ones substituted at the pyridine 3-position gave the best results (namely, $7 b-50 \%$ and $90 \%$ selectivity, $7 e-47 \%$ and $83 \%$ of selectivity, Table 1, entries 17 and 20 ), however the original PEPPSI catalyst prepared by Organ ${ }^{7}$ outperformed even them. What is more, a complex based on unsubstituted pyridine (PEPPSI-Py) ${ }^{34}$ was found to be more active and selective.

Next, the best four tested complexes were utilized in a set of Suzuki cross-coupling reactions. In most cases very good conversion and selectivity were achieved, however in some cases quinone-free catalysts were found to be slightly better than the newly obtained complexes $\mathbf{7 b}$ and $\mathbf{7 e}$ (Figure 4). The poorest results were obtained when 2-bromopyridine (9e) was used as a cross partner. Here, not only was the conversion low but also three products were formed, namely, the desired product 10ae together with homo-coupled products.

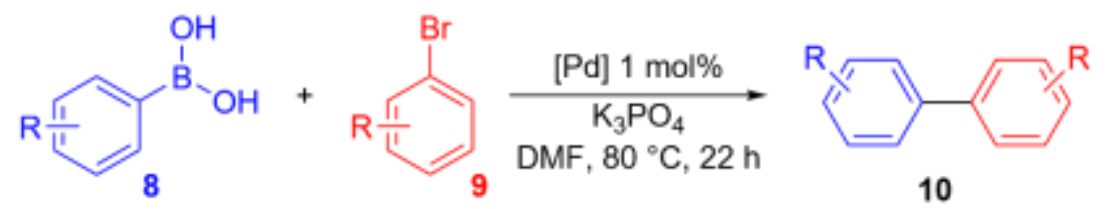

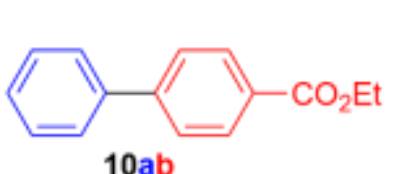

7b, $100 \%$

$7 e, 100 \%$

PEPPSI, $100 \%$

PEPPSI-Py, 100\%

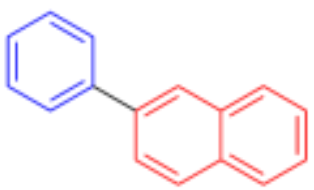

$7 \mathbf{b}, 100 \% \quad 10 a c$

7e, $100 \%$

PEPPSI, 100\%

PEPPSI-Py, 100\%

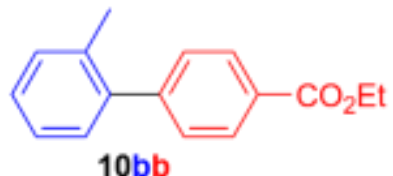

7b, $92 \%$

7e, $97 \%$

PEPPSI, 94\%

PEPPSI-Py, 97\%

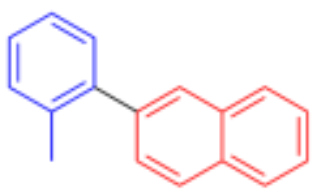

$7 \mathrm{~b}, 100 \% \quad 10 \mathrm{bc}$

7 e, $82 \%$

PEPPSI, $100 \%$

PEPPSI-Py, 100\%

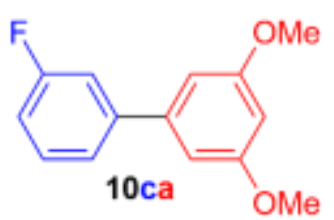

7b, $60 \%$

7 e, $60 \%$

PEPPSI, 69\%

PEPPSI-Py, 73\%

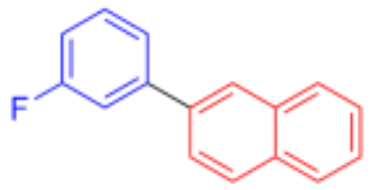

$7 \mathrm{~b}, 100 \% \quad 10 \mathrm{cc}$

7e, $100 \%$

PEPPSI, 100\%

PEPPSI-Py, $100 \%$

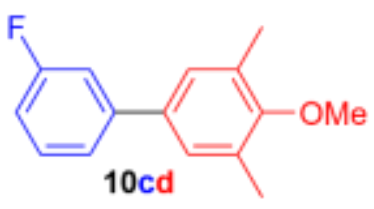

7b, $5 \%$

7 e, $36 \%$

PEPPSI, 38\%

PEPPSI-Py, 35\%

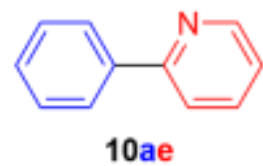

7b, $11 \%$

7 e, $7 \%$

PEPPSI, 15\%

PEPPSI-Py, $11 \%$

Figure 4. Products of Suzuki cross-coupling reactions. Conditions: 1 mol\% of PEPPSI-type catalyst, $\mathrm{K}_{3} \mathrm{PO}_{4}, \mathrm{DMF}$, $22 \mathrm{~h}$. In all cases, but 10ae, selectivity above $95 \%$ was observed. Conversion and selectivity were determined based on GC measurements with durene as an internal standard.

\section{Mizoroki-Heck reaction}

Next, another important cross-coupling reaction-the Mizoroki-Heck reaction-between chloro- (9f) or iodobenzene $(\mathbf{9 g})$ and styrene (11a) was carried out in DMF in the presence of sodium acetate at different temperatures (Scheme 4, Table 2). 


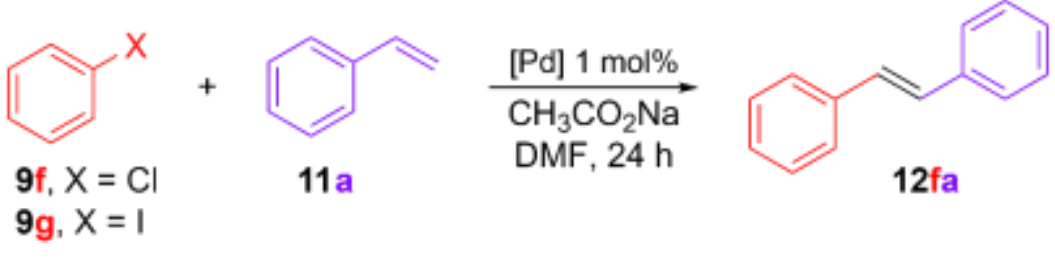

Scheme 4. Mizoroki-Heck reaction catalyzed by PEPPSI-type complexes.

Table 2. Mizoroki-Heck reaction between 9 f or $\mathbf{9 g}$ and $11 \mathrm{a}$ catalyzed by PEPPSI-type complexes

\begin{tabular}{|c|c|c|c|c|c|}
\hline Entry & $X$ & Catalyst & Temperature $\left[{ }^{\circ}\right]$ & Conversion [\%] & Selectivity [\%] \\
\hline 1 & $\mathrm{Cl}$ & $7 b$ & 140 & 0 & - \\
\hline 2 & $\mathrm{Cl}$ & PEPPSI & 140 & 0 & - \\
\hline 3 & I & $7 b$ & 80 & 35 & 93 \\
\hline 4 & I & PEPPSI & 80 & 45 & 93 \\
\hline 5 & 1 & $7 b$ & 100 & 71 & 92 \\
\hline 6 & I & PEPPSI & 100 & 99 & 92 \\
\hline 7 & I & $7 b$ & 120 & 100 & 90 \\
\hline 8 & I & PEPPSI & 120 & 100 & 90 \\
\hline 9 & I & $7 a$ & 100 & 70 & 83 \\
\hline 10 & I & 7c & 100 & 62 & 91 \\
\hline 11 & I & $7 d$ & 100 & 100 & 89 \\
\hline 12 & I & $7 e$ & 100 & 100 & 91 \\
\hline 13 & I & $7 f$ & 100 & 69 & 91 \\
\hline 14 & 1 & PEPPSI-Py & 100 & 66 & 91 \\
\hline
\end{tabular}

Conditions: 1 mol\% of PEPPSI-type catalyst, $\mathrm{CH}_{3} \mathrm{COONa}$, DMF, $24 \mathrm{~h}$. Conversion and selectivity were determined based on GC measurements with durene as an internal standard.

As expected, chlorobenzene (9f) was not active enough in the studied reaction and even at $140{ }^{\circ} \mathrm{C}$ only traces of the desired product 12fa were observed after 24 hours (Table 2, entries 1-2). The use of iodobenzene (9g) allowed for almost quantitative conversion at $100{ }^{\circ} \mathrm{C}$ (Table 2, entry 6), while at $80^{\circ} \mathrm{C}$ the conversion was in the range of $35-45 \%$ (Table 2, entries 3-4). With the increase of the temperature, there was a minimal increase in the formation of by-products. Next, the influence of the catalyst structure on the reaction was examined (Table 2, entries 5-6 and 9-14). In the case of Mizoroki-Heck reaction, significantly better results were obtained when catalysts containing a naphthoquinone moiety were used. Complexes $\mathbf{7 d}$ and $\mathbf{7 e}$ gave quantitative conversion and Pd-compound $7 \mathbf{f}$ was slightly worse, however here also almost $70 \%$ conversion was observed (Table 2 , entries 11-13). Their analogues containing benzoquinone derivatives (Table 2, entries 5, 9-10) as well as PEPPSIPy catalyst containing unsubstituted pyridine ligand (Table 2, entry 14) provided the desired product $\mathbf{1 2 f a}$ with $39-66 \%$ conversion. In all cases, the selectivity of the process was around $90-95 \%$.

Based on the results obtained, complex 7e containing 3-substituted naphthoquinone derivative was used in further experiments providing the products of cross-coupling reaction in moderate and good isolated yields (Scheme 5). 


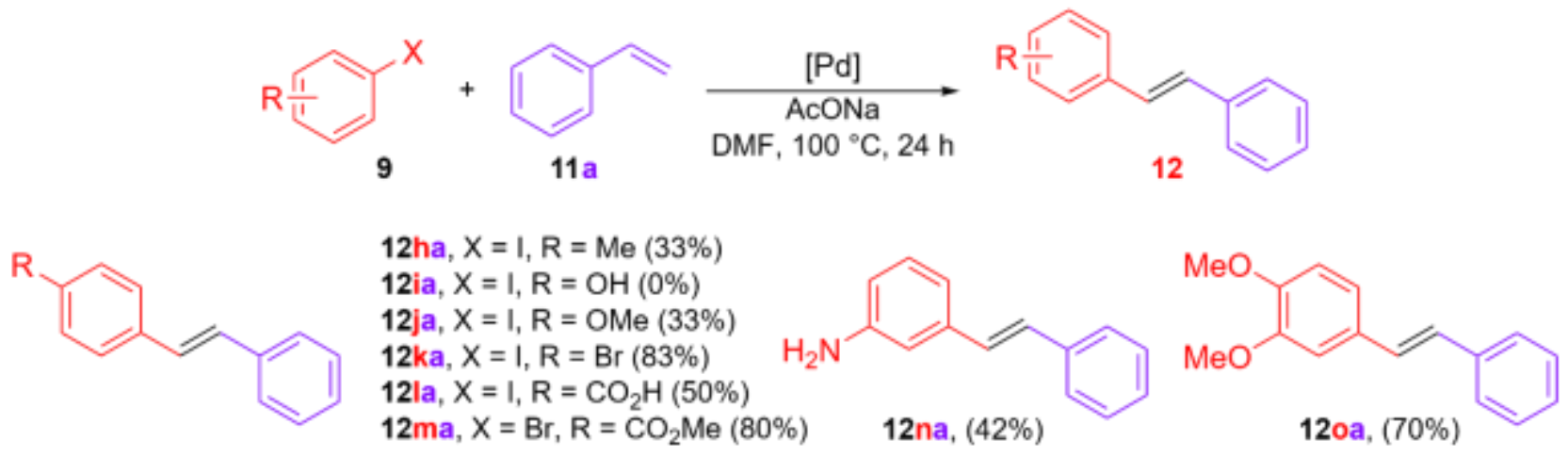

Scheme 5. Products of Mizoroki-Heck cross-coupling reactions. Conditions: $1 \mathrm{~mol} \%$ of PEPPSI-type catalyst, $\mathrm{CH}_{3} \mathrm{COONa}$, DMF, $100{ }^{\circ} \mathrm{C}, 24 \mathrm{~h}$. Isolated yields.

\section{DFT calculations}

To understand the effect of the pyridine ligand attached to the palladium catalyst, DFT calculations were developed. Earlier, however, it was discovered that the opening of the dimer 6 costs $21.7 \mathrm{kcal} / \mathrm{mol}$. Thence, the subsequent coordination of the pyridine ligand supposes a stabilization of 16.2 and $15.0 \mathrm{kcal} / \mathrm{mol}$ by the PEPPSIPy and PEPPSI, respectively. Moving on to list 7a-7f, the values are 21.0, 20.9, 16.9, 21.6, $21.3 \mathrm{and} 16.7 \mathrm{kcal} / \mathrm{mol}$, respectively. Therefore, there is a clear destabilization only when the pyridine ring is substituted at $\mathrm{C} 4$. This makes it possible to explain the results of Scheme 2, where 2-substitution, and especially 3-substitution, are favored. In an attempt to describe in more detail the nature of the different catalysts 7a-7f, structural and electronic analyses were envisaged. Starting with the length of the Pd-N bond in the eight catalysts, there are only minimal differences in the third decimal place, and it is essentially $2.13 \AA$ (see Table S1). With an attempt to go further and take into account the strength of the bond, the Mayer Bond Orders (MBO) make a small nuance. ${ }^{35,36}$ The MBOs for sequences $\mathbf{7 a - 7 c}$ and $\mathbf{7 d - 7 f}$ are almost identical and are respectively $0.39,0.40$ and 0.41.37, 38. Thus, it is observed that the Pd-N bond is strengthened by moving from 2-substitution of the pyridine ring, to the target, and even more in 4-substitution. Pd- $\mathrm{N}$ bond analysis along fails to explain the binding energy of these amine ligands, and an extended analysis of the substituents on the pyridine ring is required (vide infra).

Moving the focus to how it affects the entry of the pyridine ligand into the palladium dichloro complex, the steric maps developed by Cavallo and coworkers were used, ${ }^{39}, 40$ based on the idea of the steric index quantified as $\% V_{\text {Bur. }}{ }^{41}$ The data in Table 3 of how crowded the metal center is removing the pyridine clearly confirm that this pyridine ligand does not affect the metal environment sterically at all, with a range of \% $\mathrm{V}_{\text {Bur }}$ changing from 28.3 for $\mathbf{7 c}$ to $32.5 \%$ for $\mathbf{7 e}$, considering the position of the nitrogen atom of pyridine ring as a center (see Figure 5). The range is very small and at most allows us to see that the ligand at the 3-position in the pyridine ring is the one that mainly constrains the rest of the catalyst with values of 32.1 and $32.5 \%$ for $7 \mathbf{b}$ and $7 \mathbf{e}$, respectively. Unexpectedly, in 2-position the effect is less, with values of 29.1 and $29.2 \%$ for 7 a and $7 d$, respectively. Analyzing by quadrants, a large asymmetry motivated by the substitution or not of the pyridine ligand could not be perceived either. We suggest that this is surprising because the substituting group would be expected to affect the metallic environment more, being closer to it in the 2-position than at the 3-position. Table S2 confirms this fact, with the analysis of the pyridine ligand, and shows what space it occupies of the metal to which it binds. And really this is palpable with values moving between $19.5 \%$ for $7 c$, with 4 -substitution on its ring, up to 28.0 and $27.9 \%$ for $\mathbf{7 a}$ and $\mathbf{7 d}$, respectively, thus confirming that only this substitution greatly affects the metal directly, but the indirect interaction that its substituent makes in the second sphere of coordination of the metal 
is obvious. This is evident when the diameter is increased to calculate the\% VBur from 3.5 to $6 \AA$, ${ }^{42}$ where the occupancy due to 2- and 3-substituted pyridine are equal and even higher in the 3-substituted pyridine. Going further, now at the NHC ligand, no major change is observed either (see Table S3), where the NHC ligand is practically unaffected by the ligand trans to it with respect to the metal, which separates them.

Table 3. Effect of the PEPPSI type ligands on the PEPPSI based catalysts (\% $\mathrm{V}_{\text {Bur }}$ )

\begin{tabular}{|c|c|c|c|c|c|}
\hline Catalyst & $\% \mathrm{~V}_{\text {Bur }}$ (total) & $\% \mathrm{~V}_{\text {Bur }}(\mathrm{SW})$ & $\% \mathrm{~V}_{\text {Bur }}(\mathrm{NW})$ & $\% \mathrm{~V}_{\text {Bur }}(\mathrm{NE})$ & $\% \mathrm{~V}_{\text {Bur }}(\mathrm{SE})$ \\
\hline PEPPSI-Py & 28.5 & 23.1 & 34.0 & 23.0 & 33.9 \\
\hline PEPPSI & 30.4 & 29.8 & 34.9 & 23.4 & 33.4 \\
\hline $7 a$ & 29.1 & 21.5 & 30.1 & 27.4 & 37.6 \\
\hline $7 b$ & 32.1 & 34.9 & 35.0 & 24.1 & 34.4 \\
\hline 7c & 28.3 & 23.1 & 33.1 & 23.4 & 33.4 \\
\hline $7 d$ & 29.2 & 21.5 & 30.1 & 27.6 & 37.6 \\
\hline $7 e$ & 32.5 & 34.4 & 36.4 & 24.1 & 34.9 \\
\hline $7 f$ & 30.9 & 24.4 & 32.8 & 32.0 & 34.5 \\
\hline
\end{tabular}
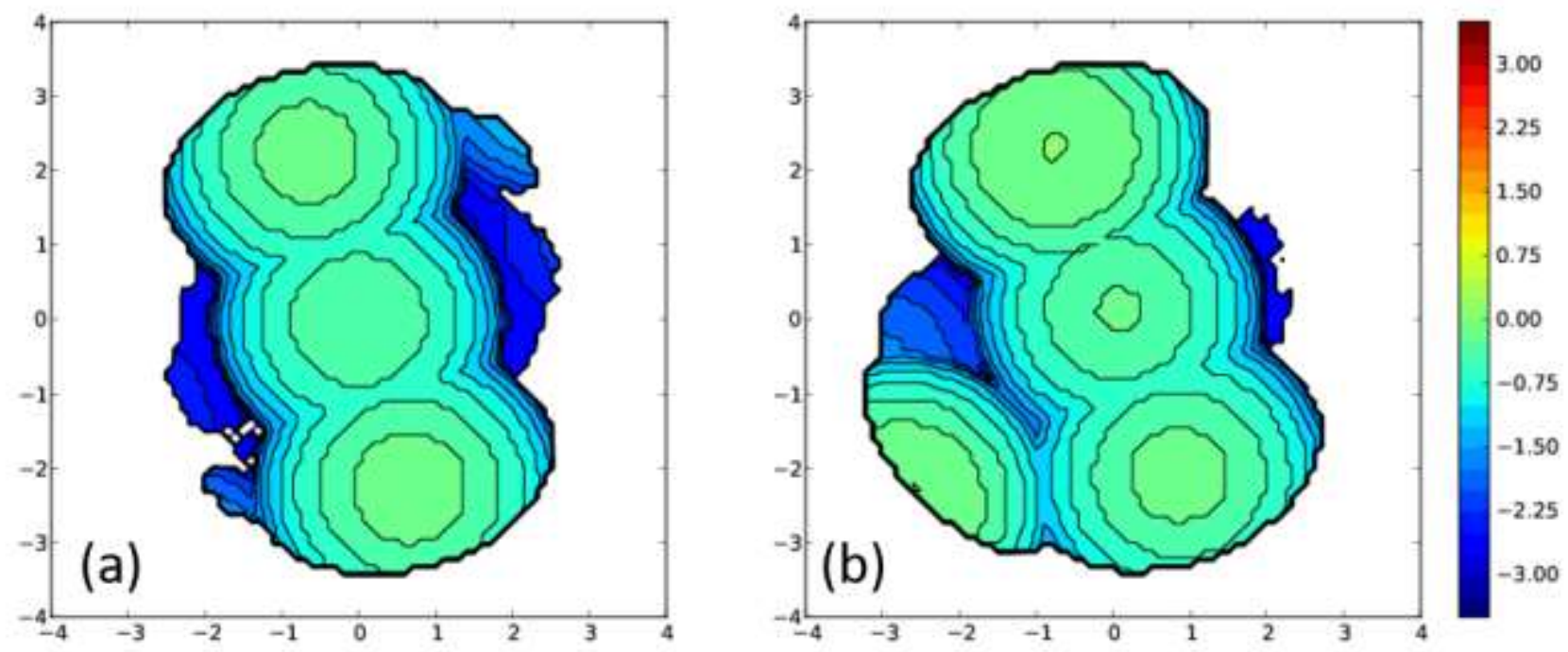

Figure 5. Steric maps (xy plane) for (a) $7 c$ and (b) 7e. The linking $N$ atom of the pyridine is at the center, whereas the metal on the $z$ axis, and $2 \AA$ below the xy plane described by the metal and both halide atoms. The isocontour curves of the steric maps are given in $\AA$.

From the point of view of NBO charges on palladium and nitrogen, there is an interesting fact for the 3substituted pyridine ring, where the polarization of charges is more pronounced, than at 4-, and much more with respect to 2-substitution. Thus, in goal, the palladium enjoys an NBO load for $7 \mathrm{~b}$ and $7 \mathrm{e}$ of 0.19 , only 0.16 for 7a and 7d. Obviously this is also valid, qualitatively and also quantitatively for PEPPSI-Py and Py, and in fact, it exemplifies in part that it does not depend on the nature of the group, but on the type of pyridine ring substitution. In addition, the conceptual DFT hints at differences between the eight complexes under analysis. ${ }^{43,}$ ${ }^{44}$ But small nuances, and the two basic PEPPSI-Py and PEPPSI systems had a chemical hardness of 0.16, and instead, the other systems 0.11 , so the latter systems might be much more reactive, and this might be then 
checked against the catalysis observed with these catalysts (see Table 2). However, the reactivity of these catalysts must be evaluated once dissociated from the pyridine based ligand, which leads to the same species for all the eight systems. Moreover, to differentiate among the series 7a-7f was not facile according to chemical hardness. The same is observed for electrophilicity, ${ }^{45}$ where PEPPSI-Py and PEPPSI only a value of 0.07, much less than 0.14 for the rest. Overall, conceptual DFT fails to distinguish between the series 7a-7f catalysts.

To account for the effect of weak forces between groups and substituents of different ligands $\mathrm{NCl}$ plots, by Contreras-Garcia and coworkers, ${ }^{46}, 47$ were performed where we were interested in weak non-covalent interactions. The $\mathrm{NCl}$ graphs in Figure 6 show in blue the attractive non-covalent interactions and in red the repulsive ones. Bearing in mind only the non-covalent interactions between the chlorides on palladium and the closest aromatic protons of the pyridine for PEPPSI-Py ligand (see Figure 6a), clearly arranged here is a favorable interaction in the form of $\pi-\pi$ stacking between an aryl group on the imidazole of the NHC and the aromatic part of the 2-substituent on the pyridine ring attached to the palladium. ${ }^{48}$ The steric map for $7 \mathbf{d}$ in Figure $6 \mathrm{~b}$ confirms this clearly, while Figure $6 c$ for $7 e$ describes other type of non-covalent interactions between the aryl group of the substituent on the pyridine ring and hydrogen atoms of the substituents on the imidazole of the $\mathrm{NHC}$, i.e. a sort of T-shape interaction. ${ }^{49}$
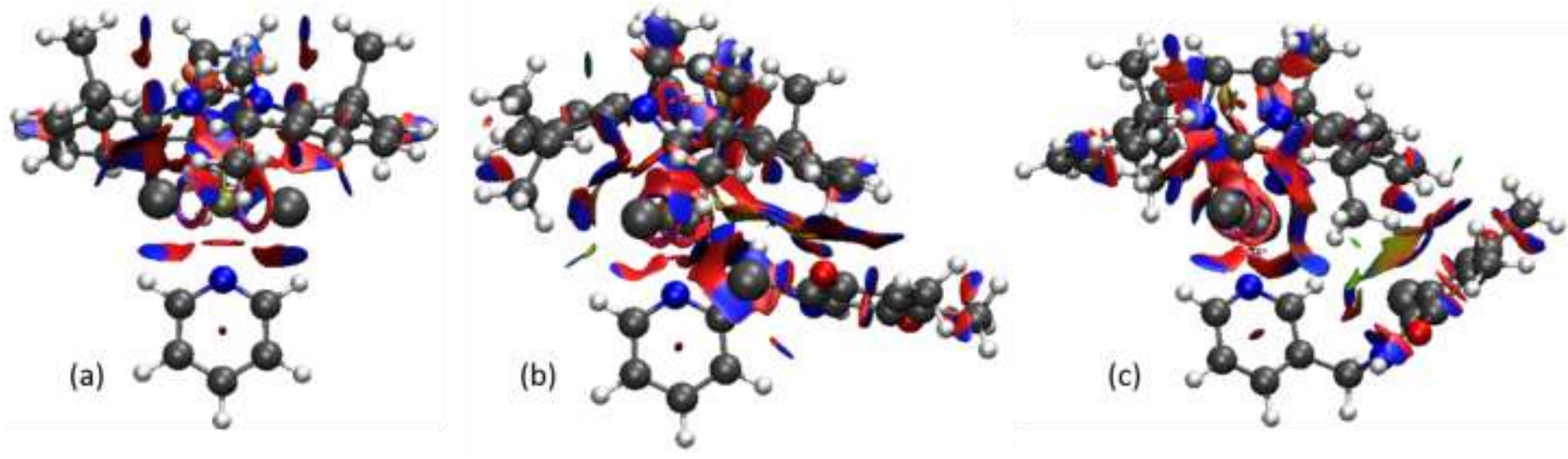

Figure 6. $\mathrm{NCI}$ plots (a) PEPPSI-Py, (b) 7d and (c) 7e. The isosurface represents a value of 0.5 with a color scale for the reduced density gradient from -0.05 (blue) to 0.05 (red).

The catalytically active species is identical for any of the eight PEPPSI-based catalysts, as it corresponds to the bis-chloride species once these pyridine-derived ligands are dissociated. This structure, relatively unstable, in order to avoid its tendency to redimerize, interacts with the base. In particular, for $\mathrm{K}_{3} \mathrm{PO}_{4}$, the best base at the experimental level according to Table 2, it supposes a stabilization of $28.8 \mathrm{kcal} / \mathrm{mol}$, with one of the oxygens of the base coordinated trans to the NHC ligand. Obviously the exchange of the pyridine ligand for the solvent, $\mathrm{DMF}$, was studied, but this step only releases $4.4 \mathrm{kcal} / \mathrm{mol}$, and kinetically in any case it is not a dissociative but concerted procedure, ${ }^{50}$ it would also generate a kinetic barrier of at least $10.0 \mathrm{kcal} / \mathrm{mol}$ for any of the systems studied.

\section{Conclusions}

We have synthesized six new PEPPSI type complexes featuring a quinone moiety on pyridine ligands. They were fully characterized and utilized in cross-coupling reactions. In Suzuki reactiona, the best results were obtained 
in the presence of complexes possessing quinone substituent at the 3-position, $\mathbf{7 b}$ and $\mathbf{7 e}$, which were comparable or only slightly worse to these obtained in the presence of the parent PEPPSI catalysts developed by Organ. In Mizoroki-Heck reactions, naphthoquinone-based catalysts performed best.

Mechanistically, the big question was to resolve whether there was a difference and why among the eight PEPPSI-type catalysts studied for cross-coupling reaction-type catalysis. By DFT calculations, structurally and electronically no ostensible differences were seen. In addition the formation of the catalytic active $\mathrm{Pd}(0)$ species is not crucial, but the $\mathrm{NCl}$ plots allowed us to discover why the substitution at 3-, and especially at 2-position, does not disfavor the formation of the PEPPSI-type complexes that include these ligands.

\section{Experimental Section}

\section{General}

Unless otherwise noted, all reactions were conducted under argon atmosphere. Flash column chromatography was carried out using Merck silica gel 60 (230-400 mesh). NMR $\left({ }^{1} \mathrm{H},{ }^{13} \mathrm{C}\right)$ spectra were recorded on Varian Gemini 500 spectrometer; samples were dissolved in $\mathrm{CDCl}_{3}$; chemical shifts $(\delta)$ are relative to $\mathrm{CDCl}_{3}$. IR spectra were recorded on Perkin-Elmer Spectrum 2000 and 1170 FT-IR spectrometers. ESI MS were recorded on an instrument from Mariner PerSeptive Biosystems, Inc. Mass spectra were obtained using either LCQ Finnigan or Mariner PerSeptive Biosystems, Inc. instruments, using electrospray ionization (ESI) mode, or AMD 604 Intectra $\mathrm{GmbH}$ instrument, using electron impact ionization (EI). Ion mass $(\mathrm{m} / \mathrm{z})$ signals are reported as values in atomic mass units followed, in parentheses, by the peak intensities relative to the base peak (100\%). GC analyses were conducted on a HP 6890 chromatograph with a HP 5 column. Elemental analyses were provided by the Institute of Organic Chemistry, PAS, Warsaw.

General procedure for the synthesis of pyridine ligands: To a suspension of quinone $(2.2 \mathrm{mmol})$ in $\mathrm{EtOH}(10$ $\mathrm{mL})$, aminomethyl pyridine $(2 \mathrm{mmol})$ was added dropwise at $0{ }^{\circ} \mathrm{C}$. The mixture was warmed up to $\mathrm{rt}$ and the mixture was stirred for $24 \mathrm{~h}$. The solvent was evaporated and the residue was purified using column chromatography (10-50\% EtOAc/c-Hex).

\section{2-Chloro-5,6-dimethyl-3-((pyridin-2-ylmethyl)amino)cyclohexa-2,5-diene-1,4-dione (3a)}

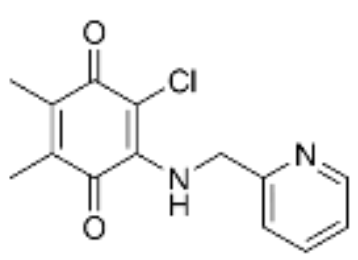

Yield 47\%; ${ }^{1} \mathrm{H}$ NMR $\left(500 \mathrm{MHz}, \mathrm{CDCl}_{3}\right) \delta=8.62(\mathrm{~d}, J 4.8 \mathrm{~Hz}, 1 \mathrm{H}), 7.72(\mathrm{dt}, J 1.7,7.8 \mathrm{~Hz}, 1 \mathrm{H})$, 7.41 (br s, 1H), 7.24-7.30 (m, 2H), 5.09 (d, J $5.4 \mathrm{~Hz}, 2 \mathrm{H}), 2.10$ (d, J $1.1 \mathrm{~Hz}, 3 \mathrm{H}), 2.02$ (t, J 1.1 $\mathrm{Hz}, 3 \mathrm{H}) \mathrm{ppm} ;{ }^{13} \mathrm{C}$ NMR $\left(125 \mathrm{MHz}, \mathrm{CDCl}_{3}\right) \delta=182.6,179.1,155.4,148.8,143.7,142.3$, $137.2,122.7,121.9,107.4,48.3,13.4,12.2 \mathrm{ppm}$; MS (EI) $\mathrm{m} / \mathrm{z}(\%): 241\left(\mathrm{M}-\mathrm{Cl}^{+*}, 100\right)$, 213(22), 93(32), 92(26); IR $\left(\mathrm{CH}_{2} \mathrm{Cl}_{2}\right.$ film): $\tilde{v}=3243,1667,1650,1592,1565,1497,1432$, $1377,1304,1204,1167,1088,997.830,808,763,723,558,457 \mathrm{~cm}^{-1}$; Elemental analysis calcd. (\%) for $\mathrm{C}_{14} \mathrm{H}_{13} \mathrm{ClN}_{2} \mathrm{O}_{2}$ : C 60.77, H 4.74, N 10.12; found C 60.59, H 4.64, N 10.05.

\section{2-Chloro-5,6-dimethyl-3-((pyridin-3-ylmethyl)amino)cyclohexa-2,5-diene-1,4-dione (3b)}

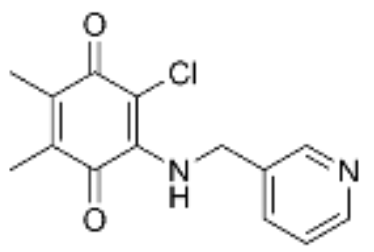

Yield 49\%; ${ }^{1} \mathrm{H}$ NMR $\left(500 \mathrm{MHz}, \mathrm{CDCl}_{3}\right) \delta=8.58(\mathrm{~s}, 1 \mathrm{H}), 8.57(\mathrm{~d}, J 1.2 \mathrm{~Hz}, 1 \mathrm{H}), 7.65(\mathrm{~d}, J 7.9$ $\mathrm{Hz}, 1 \mathrm{H}), 7.32$ (dd, J 4.9, $7.8 \mathrm{~Hz}, 1 \mathrm{H}), 6.01$ (br s, 1H), 4.98 (d, J $6.6 \mathrm{~Hz}, 2 \mathrm{H}), 2.09$ (d, J $1.1 \mathrm{~Hz}$, $3 \mathrm{H}), 2.00$ (d, J $1.1 \mathrm{~Hz}, 3 \mathrm{H}$ ) ppm; ${ }^{13} \mathrm{C}$ NMR $\left(125 \mathrm{MHz}, \mathrm{CDCl}_{3}\right) \delta=182.3,179.1,149.0,148.7$, $143.9,141.6,136.5,135.3,134.0,123.8,108.1,45.8,13.4,12.2 \mathrm{ppm}$; MS (EI) $\mathrm{m} / z$ (\%): $276\left(\mathrm{M}^{+*}, 76\right), 241\left(\mathrm{M}-\mathrm{Cl}^{++}, 27\right), 198(27), 92(100), 65(44), 36(26) ; \operatorname{IR}\left(\mathrm{CH}_{2} \mathrm{Cl}_{2}\right.$ film): $\tilde{v}=3329$, $3031,1662,1594,1510,1426,1377,1306,1242,1164,1084,1027,813,713,559,431 \mathrm{~cm}^{-1}$; elemental analysis calcd. (\%) for $\mathrm{C}_{14} \mathrm{H}_{13} \mathrm{ClN}_{2} \mathrm{O}_{2}$ : C 60.77, H 4.74, N 10.12; found C 60.68, H 4.62, N 10.12 . 


\section{2-Chloro-5,6-dimethyl-3-((pyridin-4-ylmethyl)amino)cyclohexa-2,5-diene-1,4-dione (3c)}

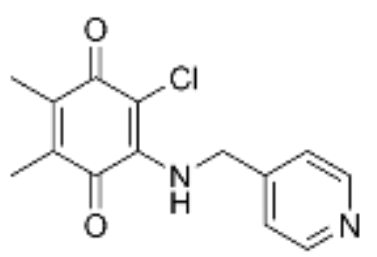

Yield 45\%; ${ }^{1} \mathrm{H}$ NMR $\left(500 \mathrm{MHz}, \mathrm{CDCl}_{3}\right) \delta=8.58-8.60(\mathrm{~m}, 2 \mathrm{H}), 7.20(\mathrm{~d}, J 5.9 \mathrm{~Hz}, 2 \mathrm{H}), 6.11$ (br s, 1H), $4.96(\mathrm{~d}, J 6.8 \mathrm{~Hz}, 2 \mathrm{H}), 2.09(\mathrm{~d}, J 0.9 \mathrm{~Hz}, 3 \mathrm{H}), 2.02(\mathrm{~d}, J 0.9 \mathrm{~Hz}, 3 \mathrm{H}) \mathrm{ppm} ;{ }^{13} \mathrm{C}$ NMR $\left(125 \mathrm{MHz}_{1} \mathrm{CDCl}_{3}\right) \delta=182.3,179.1,150.2,147.7,143.9,141.7,136.5,121.7,46.9,13.4$, 12.2 ppm; MS (EI) m/z (\%): $276\left(\mathrm{M}^{+*}, 100\right), 241\left({\left.\mathrm{M}-\mathrm{Cl}^{+*}, 83\right),}, 98\right.$ (73), 92 (46), 65 (40); IR

$\left(\mathrm{CH}_{2} \mathrm{Cl}_{2}\right.$ film $): \tilde{v}=3333,1663,1591,1511,1416,1306,1244,1164,1083,932,814,793$, $772,721,616,559,430 \mathrm{~cm}^{-1}$; elemental analysis calcd. (\%) for $\mathrm{C}_{14} \mathrm{H}_{13} \mathrm{ClN}_{2} \mathrm{O}_{2}: \mathrm{C} 60.77, \mathrm{H} 4.74, \mathrm{~N} \mathrm{10.12;} \mathrm{Cl} 12.81$; found C 60.59, H 4.95, N 9.86, Cl 12.88 .

\section{2-Chloro-3-((pyridin-2-ylmethyl)amino)naphthalene-1,4-dione (3d)}

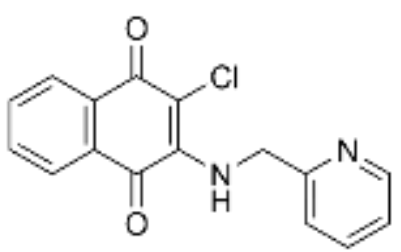

Yield 56\%; ${ }^{1} \mathrm{H}$ NMR (500 MHz, DMSO) $\delta=8.55(\mathrm{~d}, J 4.5 \mathrm{~Hz}, 1 \mathrm{H}), 8.08-8.12(\mathrm{~m}, 2 \mathrm{H}), 8.00$ (d, J 7.2 Hz, 2H), 7.84-7.87 (m, 2H), $7.42(\mathrm{~d}, J 7.8 \mathrm{~Hz}, 1 \mathrm{H}), 7.3(\mathrm{t}, J 6.6 \mathrm{~Hz}, 1 \mathrm{H}), 5.10(\mathrm{~d}, J$ $6.0 \mathrm{~Hz}, 2 \mathrm{H}) \mathrm{ppm}$. Other data corresponding to this compound are described in the literature. ${ }^{30}$

\section{2-Chloro-3-((pyridin-3-ylmethyl)amino)naphthalene-1,4-dione (3e)}

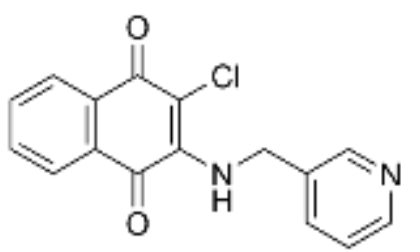

Yield 50\%; ${ }^{1} \mathrm{H}$ NMR $\left(500 \mathrm{MHz}, \mathrm{CDCl}_{3}\right) \delta=8.63(\mathrm{~d}, J$ 1,7 Hz, $1 \mathrm{H}), 8.58(\mathrm{dd}, J$ 1.1, $4.8 \mathrm{~Hz}$, $1 \mathrm{H}), 8.14(\mathrm{dd}, J 0.8,7.7 \mathrm{~Hz}, 1 \mathrm{H}), 8.04(\mathrm{dd}, J 0.8,7.7 \mathrm{~Hz}, 1 \mathrm{H}), 7.74(\mathrm{dt}, J 1.2,7.5 \mathrm{~Hz}, 1 \mathrm{H})$, $7.68(\mathrm{~d}, J 7.8 \mathrm{~Hz}, 1 \mathrm{H}), 7.64(\mathrm{dt}, J 1.1,7.5 \mathrm{~Hz}, 1 \mathrm{H}), 7.33$ (dd, J 4.8, 7.8 Hz, 1H), 6.27 (br s, $1 \mathrm{H}), 5.09(\mathrm{~d}, J 6.5 \mathrm{~Hz}, 2 \mathrm{H}) \mathrm{ppm}$. Other data corresponding to this compound are given in the literature. ${ }^{30}$

\section{2-Chloro-3-((pyridin-4-ylmethyl)amino)naphthalene-1,4-dione (3f)}

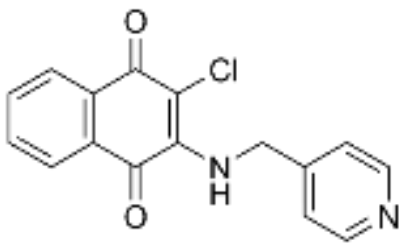

Yield 34\%; ${ }^{1} \mathrm{H}$ NMR $\left(500 \mathrm{MHz}, \mathrm{CDCl}_{3}\right) \delta=8.60-8.63(\mathrm{~m}, 2 \mathrm{H}), 8.15$ (dd, J 0.6, 7.4 Hz, $\left.1 \mathrm{H}\right)$, $8.05(\mathrm{dd}, J=0.6,7.7 \mathrm{~Hz}, 1 \mathrm{H}), 7.72-7.77(\mathrm{~m}, 1 \mathrm{H}), 7.63-7.68(\mathrm{~m}, 1 \mathrm{H}), 7.24-7.27(\mathrm{~m}, 2 \mathrm{H})$, 6.41 (br s, 1H), 5.07 (d, J 6.8 Hz. 2H) ppm; ${ }^{13} \mathrm{C}$ NMR (125 MHz, CDCl $\left.{ }_{3}\right) \delta=180.2,176.9$, 150.2, 147.6, 143.8, 135.1, 132.8, 132.4, 129.7, 127.0, 126.9, 121.8, 121.7, 47.3 ppm; MS (ESI, MeOH): $m / z=299[\mathrm{M}+\mathrm{H}]^{+} ;$IR $\left(\mathrm{CH}_{2} \mathrm{Cl}_{2}\right.$ film): $\tilde{v}=3331,1677,1599,1573,1514$, $1415,1332,1297,1252,1139,1068,996,937,871,840,791,721,681,610,545,479 \mathrm{~cm}^{-1}$; elemental analysis calcd. (\%) for $\mathrm{C}_{16} \mathrm{H}_{11} \mathrm{ClN}_{2} \mathrm{O}_{2}$ : C 64.33, H 3.71, N 9.38; found C 64.39, H 3.93, N 9.44.

General procedure for the synthesis of PEPPSI-type complexes: An oven-dried Schlenk tube equipped with a magnetic stir bar was charged with the palladium dimer $(50 \mathrm{mg}, 0.044 \mathrm{mmol}, 1$ equiv.) and the indicated pyridine derivative (2 equiv.) followed by DCM $(1 \mathrm{~mL})$. The solution was stirred at $\mathrm{rt}$ for $2 \mathrm{~h}$, whereupon it was filtered through a short plug of silica and eluted with DCM. Solvent was removed under reduced pressure to afford the pure product.

PEPPSI-o-BQ (7a)

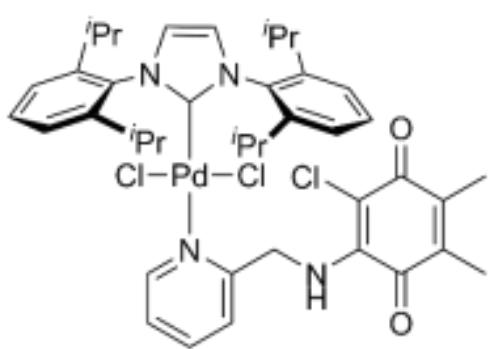

Yield 90\%; ${ }^{1} \mathbf{H}$ NMR $\left(500 \mathrm{MHz}, \mathrm{CDCl}_{3}\right) \delta=8.29(\mathrm{~d}, J 4.7 \mathrm{~Hz}, 1 \mathrm{H}), 7.54(\mathrm{dt}, J$ 1.3, 7.7 $\mathrm{Hz}, 2 \mathrm{H}), 7.36$ (br s, 5H), 7.13-7.23 (m, 3H), 7.04-7.08 (dt, J 0.9, $6.0 \mathrm{~Hz}, 1 \mathrm{H}), 6.40$ (br s, 1H), 5.34(d, J $6.8 \mathrm{~Hz}, 2 \mathrm{H}), 2.12$ (d, J $0.9 \mathrm{~Hz}, 3 \mathrm{H}), 2.02$ (d, J $0.9 \mathrm{~Hz}, 3 \mathrm{H}), 1.43$ $(\mathrm{s}, 12 \mathrm{H}), 1.10(\mathrm{~s}, 12 \mathrm{H}) \mathrm{ppm} ;{ }^{13} \mathrm{C}$ NMR $\left(125 \mathrm{MHz}, \mathrm{CDCl}_{3}\right) \delta=182.0,179.2,158.4$, $155.9,150.6,147.0,143.3,141.7,137.9,136.5,135.0,130.2,124.9,124.4,123.8$, $123.4,48.9,28.8,26.5,23.0,13.4,12.3 . \mathrm{ppm} ; \mathrm{MS}(\mathrm{ESI}, \mathrm{MeOH}): \mathrm{m} / \mathrm{z}=841[\mathrm{M}+\mathrm{H}]^{+}$, $863[\mathrm{M}+\mathrm{Na}]^{+} ;$IR $\left(\mathrm{CH}_{2} \mathrm{Cl}_{2}\right.$ film $): \tilde{v}=2965,2868,1663,1594,1514,1466,1444$, $1413,1382,1349,1305,1243,1163,1085,1060,803,758,737,706 \mathrm{~cm}^{-1}$; elemental analysis calcd. (\%) for $\mathrm{C}_{41} \mathrm{H}_{49} \mathrm{Cl}_{3} \mathrm{~N}_{4} \mathrm{O}_{2} \mathrm{Pd}: \mathrm{C}, 58.44 ; \mathrm{H}, 5.86 ; \mathrm{Cl}, 12.62 ; \mathrm{N}, 6.65$; found $\mathrm{C}, 58.34 ; \mathrm{H}, 6.02 ; \mathrm{Cl}, 12.40 ; \mathrm{N}, 6.36$. 


\section{PEPPSI- $m-B Q(7 b)$}

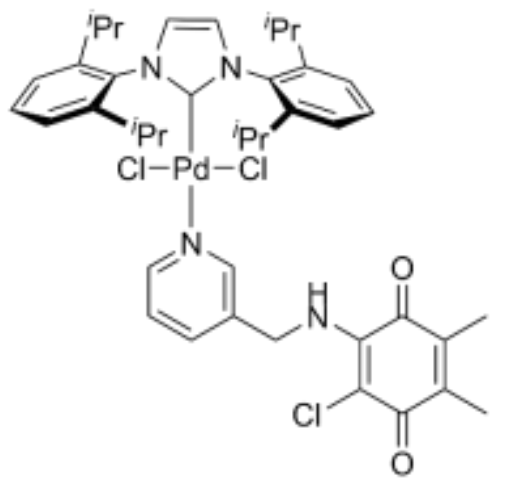

Yield 80\%; ${ }^{1} \mathrm{H}$ NMR $\left(500 \mathrm{MHz}, \mathrm{CDCl}_{3}\right) \delta=8.55-8.50(\mathrm{~m}, 2 \mathrm{H}), 7.54-7.45(\mathrm{~m}, 3 \mathrm{H})$, $7.35(\mathrm{~s}, 2 \mathrm{H}), 7.33(\mathrm{~s}, 2 \mathrm{H}), 7.14-7.08(\mathrm{~m}, 3 \mathrm{H}), 5.79(\mathrm{t}, J 7.0 \mathrm{~Hz}, 1 \mathrm{H}), 4.79(\mathrm{~d}, J 6.7$ $\mathrm{Hz}, 2 \mathrm{H}), 3.15$ (sept, J $6.7 \mathrm{~Hz}, 4 \mathrm{H}), 2.06(\mathrm{~s}, 3 \mathrm{H}), 1.97$ (s, 3H), 1.47 (d, J $6.6 \mathrm{~Hz}, 12 \mathrm{H})$, 1.11 (d, J $6.9 \mathrm{~Hz}, 12 \mathrm{H}$ ) ppm; ${ }^{13} \mathrm{C}$ NMR $\left(125 \mathrm{MHz}, \mathrm{CDCl}_{3}\right) \delta=182.1,179.1,154.3$, $150.8,150.4,146.6,143.5,141.5,136.7,136.6,135.0,134.6,130.3,125.1,124.0$, 124.0, 45.3, 28.7, 26.3, 23.2, 13.36, $12.2 \mathrm{ppm}$; MS (ESI, MeOH): $\mathrm{m} / z=862.7$ $[\mathrm{M}+\mathrm{Na}]^{+}$; IR $\left(\mathrm{CH}_{2} \mathrm{Cl}_{2}\right.$ film $): \tilde{v}=3335,2965,2928,2868,1663,1595,1509,1465$, $1442,1412,1381,1331,1306,1243,1164,1086,1059,942,804,759,736,702$ $\mathrm{cm}^{-1}$; elemental analysis calcd. (\%) for $\mathrm{C}_{41} \mathrm{H}_{49} \mathrm{Cl}_{3} \mathrm{~N}_{4} \mathrm{O}_{2} \mathrm{Pd}$ : $\mathrm{C}, 58.44 ; \mathrm{H}, 5.86 ; \mathrm{Cl}$,

$12.62 ; \mathrm{N}, 6.65$; found $\mathrm{C}, 58.57 ; \mathrm{H}, 6.22 ; \mathrm{Cl}, 12.21 ; \mathrm{N}, 6.28$.

\section{PEPPSI-p-BQ (7c)}

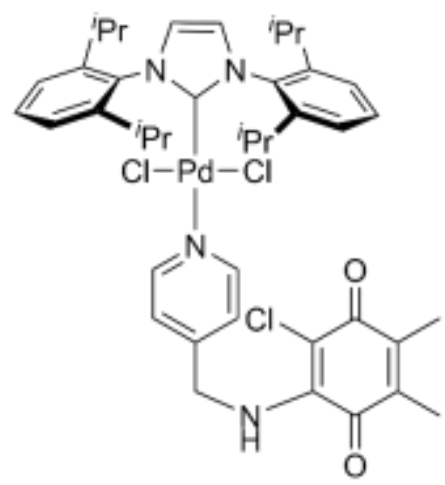

Yield 75\%; ${ }^{1} \mathrm{H}$ NMR $\left(500 \mathrm{MHz}, \mathrm{CDCl}_{3}\right) \delta=8.57-8.49(\mathrm{~m}, 2 \mathrm{H}), 7.48(\mathrm{t}, J 7.78 \mathrm{~Hz}, 2 \mathrm{H})$, $7.34(\mathrm{~s}, 2 \mathrm{H}), 7.33(\mathrm{~s}, 2 \mathrm{H}), 7.12(\mathrm{~s}, 2 \mathrm{H}), 6.99(\mathrm{~d}, J 6.71 \mathrm{~Hz}, 2 \mathrm{H}), 5.88(\mathrm{t}, J 7.03 \mathrm{~Hz}, 1 \mathrm{H})$, 4.78 (d, J $7.11 \mathrm{~Hz}, 2 \mathrm{H}$ ), 3.16 (sept, J $6.73 \mathrm{~Hz}, 4 \mathrm{H}), 2.05$ (s, 3H), 1.96 (s, 3H), 1.47 (d, J $6.59 \mathrm{~Hz}, 12 \mathrm{H}), 1.11$ (d, J $6.87 \mathrm{~Hz}, 12 \mathrm{H}) \mathrm{ppm} ;{ }^{13} \mathrm{C} \mathrm{NMR}\left(125 \mathrm{MHz}, \mathrm{CDCl}_{3}\right) \delta=182.1$, $178.9,154.6,151.6,149.6,146.6,143.6,141.4,136.6,135.1,130.2,125.0,124.0$, 122.0, 46.5, 28.7, 26.3, 23.2, 13.4, $12.2 \mathrm{ppm}$; MS (EI) $\mathrm{m} / \mathrm{z}(\%): 841[\mathrm{M}]^{+*} ;$ IR $\left(\mathrm{CH}_{2} \mathrm{Cl}_{2}\right.$ film): $\tilde{v}=3334,2965,2928,2868,1663,1596,1510,1466,1427,1412,1381,1306$, $1244,1164,1065,943,803,759,735,705 \mathrm{~cm}^{-1}$; elemental analysis calcd. (\%) for $\mathrm{C}_{41} \mathrm{H}_{49} \mathrm{Cl}_{3} \mathrm{~N}_{4} \mathrm{O}_{2} \mathrm{Pd}$ : C, 58.44; $\mathrm{H}, 5.86 ; \mathrm{Cl}, 12.62 ; \mathrm{N}, 6.65$; found $\mathrm{C}, 57.99 ; \mathrm{H}, 5.74 ; \mathrm{Cl}$,

$12.29 ; \mathrm{N}, 6.48$.

\section{PEPPSI-o-NQ (7d)}

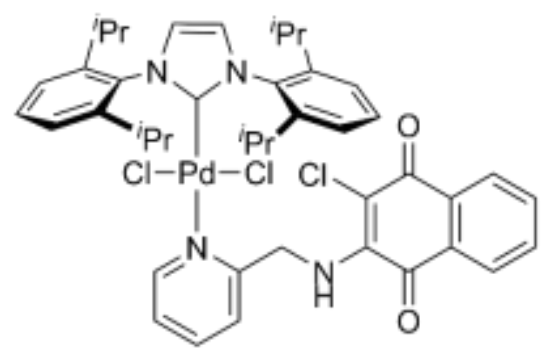

Yield 96\%; ${ }^{1} \mathrm{H}$ NMR $\left(500 \mathrm{MHz}, \mathrm{CDCl}_{3}\right) \delta=8.32(\mathrm{dd}, J 5.6,1.7 \mathrm{~Hz}, 1 \mathrm{H}), 8.19$ (dd, J 7.8, 1.3 Hz, 1H), 8.06 (dd, J 7.7, $1.3 \mathrm{~Hz}, 1 \mathrm{H}$ ), 7.76 (td, J 7.6, $1.4 \mathrm{~Hz}, 1 \mathrm{H}$ ), 7.66 (td, J 7.6, 1.4 Hz, 1H), 7.56 (td, J 7.7, 1.7 Hz, 2H), 7.40-7.22 (m 7H), 7.17 (s, 2H), 7.09 (ddd, J 7.3, 5.6, $1.4 \mathrm{~Hz}, 1 \mathrm{H}$ ), $6.68(\mathrm{~s}, 1 \mathrm{H}), 5.47$ (d, J $7.0 \mathrm{~Hz}, 2 \mathrm{H}), 3.14$ (s, 4H), 1.45 (s, 12H), 1.09 (s, 12H) ppm; ${ }^{13} \mathrm{C}$ NMR (125 MHz, CDCl 3 ) $\delta=180.0$, $176.9,158.1,155.8,150.6,147.0,143.9,138.0,134.7,132.5,130.2,126.9$, 126.7, 125.0, 124.7, 123.8, 123.5, 49.4, 28.8, 26.5 ppm ; HRMS ESI calcd. for $\mathrm{C}_{43} \mathrm{H}_{48} \mathrm{Cl}_{3} \mathrm{~N}_{4} \mathrm{O}_{2} \mathrm{Pd}[\mathrm{M}+\mathrm{H}]^{+}$863.1878, found 863.1861; IR $\left(\mathrm{CH}_{2} \mathrm{Cl}_{2}\right.$ film): $\mathrm{v}=2965,2928,2868,1677,1601,1573$, $1515,1463,1413,1331,1294,1249,1218,1139,803,768,722,707 \mathrm{~cm}^{-1}$.

\section{PEPPSI-m-NQ (7e)}

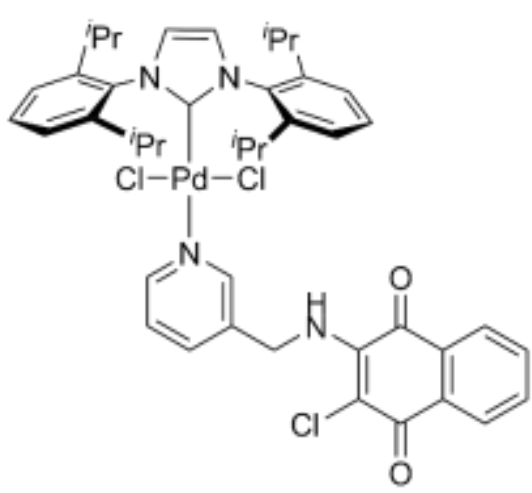

Yield 91\%; ${ }^{1} \mathbf{H}$ NMR $\left(500 \mathrm{MHz}, \mathrm{CDCl}_{3}\right) \delta=8.57(\mathrm{~d}, J 1.6 \mathrm{~Hz}, 1 \mathrm{H}), 8.55(\mathrm{~d}, J 5.5$ Hz. $1 \mathrm{H}), 8.13$ (dd, J 0.8, $7.8 \mathrm{~Hz}, 1 \mathrm{H}), 8.01(\mathrm{dd}, J 0.8,7.6 \mathrm{~Hz}, 1 \mathrm{H}), 7.72(\mathrm{dt}, J 1.2$, $7.6 \mathrm{~Hz}, 1 \mathrm{H}), 7.63(\mathrm{dt}, J 1.2,7.6 \mathrm{~Hz}, 1 \mathrm{H}), 7.55-7.59(\mathrm{~m}, 1 \mathrm{H}), 7.47(\mathrm{t}, J 7.7 \mathrm{~Hz}, 2 \mathrm{H})$, $7.33(\mathrm{~d}, J 7.7 \mathrm{~Hz}, 4 \mathrm{H}), 7.09-7.17(\mathrm{~m}, 3 \mathrm{H}), 6.03(\mathrm{br} \mathrm{s}, 1 \mathrm{H}), 4.92(\mathrm{~d}, J 6.6 \mathrm{~Hz}, 2 \mathrm{H})$, 3.15 (sept, J $6.7 \mathrm{~Hz}, 4 \mathrm{H}), 1.46(\mathrm{~d}, J 6.7 \mathrm{~Hz}, 12 \mathrm{H}), 1.11$ (d, J $6.7 \mathrm{~Hz}, 12 \mathrm{H}) \mathrm{ppm}$; ${ }^{13} \mathrm{C}$ NMR $\left(125 \mathrm{MHz}, \mathrm{CDCl}_{3}\right) \delta=180.0,176.8,154.3,151.0,150.5,146.6,143.7$, $136.7,135.0,134.8,134.4,132.7,132.3,130.3,129.8,126.9,126.8,125.0$, 124.1, 124.0, 45.6, 28.7, 26.3, $23.2 \mathrm{ppm}$; MS (ESI): $\mathrm{m} / \mathrm{z}=865[\mathrm{M}+\mathrm{H}]^{+}, 887$ $[\mathrm{M}+\mathrm{Na}]^{+} ;$IR $\left(\mathrm{CH}_{2} \mathrm{Cl}_{2}\right.$ film $): \tilde{v}=3330,2965,2982,2868,1677,1647,1602,1573$, $1512,1465,1412,1332,1295,1254,1139,1059,943,804,759,735,702 \mathrm{~cm}^{-}$ 1; elemental analysis calcd. (\%) for $\mathrm{C}_{43} \mathrm{H}_{47} \mathrm{Cl}_{3} \mathrm{~N}_{4} \mathrm{O}_{2} \mathrm{Pd}$ : C, 59.73; $\mathrm{H}, 5.48 ; \mathrm{N}, 6.48$; found $\mathrm{C}, 59.80 ; \mathrm{H}, 5.78 ; \mathrm{N}, 6.09$. 


\section{PEPPSI-p-NQ (7f)}

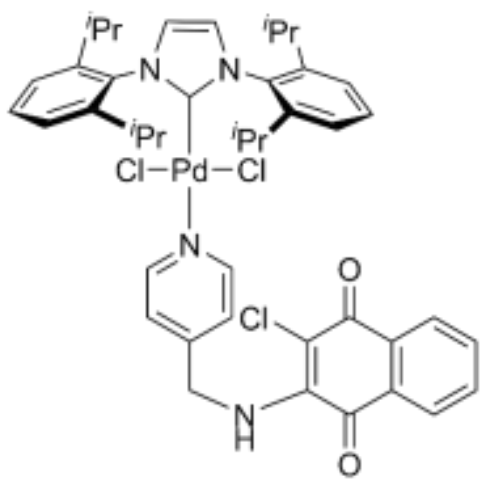

Yield 75\%; ${ }^{1} \mathrm{H}$ NMR $\left(500 \mathrm{MHz}, \mathrm{CDCl}_{3}\right) \delta=\delta 8.55(\mathrm{~d}, J 6.7 \mathrm{~Hz}, 2 \mathrm{H}), 8.11$ (dd, J 7.6, $1.3 \mathrm{~Hz}, 1 \mathrm{H}), 8.02-7.96(\mathrm{~m}, 1 \mathrm{H}), 7.71$ (td, J 7.6, $1.4 \mathrm{~Hz}, 1 \mathrm{H}), 7.62$ (td, J 7.6, $1.3 \mathrm{~Hz}$, $1 \mathrm{H}), 7.47(\mathrm{t}, J 7.8 \mathrm{~Hz}, 2 \mathrm{H}), 7.33(\mathrm{~d}, J 7.8 \mathrm{~Hz}, 4 \mathrm{H}), 7.12(\mathrm{~s}, 2 \mathrm{H}), 7.04(\mathrm{~d}, J 6.7 \mathrm{~Hz}, 2 \mathrm{H})$, $6.13(\mathrm{~s}, 1 \mathrm{H}), 4.89(\mathrm{~d}, J 7.0 \mathrm{~Hz}, 2 \mathrm{H}), 3.16(\operatorname{sept}, J 6.7 \mathrm{~Hz}, 4 \mathrm{H}), 1.47(\mathrm{~d}, J 6.6 \mathrm{~Hz}, 12 \mathrm{H}$ ), 1.11 (d, J $6.9 \mathrm{~Hz}, 12 \mathrm{H})$ ppm; ${ }^{13} \mathrm{C}$ NMR $\left(125 \mathrm{MHz}, \mathrm{CDCl}_{3}\right) \delta=180.0,176.7,154.6$, 151.6, 149.4, 146.6, 143.6, 135.1, 135.0, 132.8, 132.2, 130.2, 129.7, 127.0, 126.9, 125.0, 124.2, 124.0, 124.0, 122.0, 46.8, 28.7, 26.3, 23.2 ppm; HRMS ESI calcd. for $\mathrm{C}_{43} \mathrm{H}_{48} \mathrm{Cl}_{3} \mathrm{~N}_{4} \mathrm{O}_{2} \mathrm{Pd}[\mathrm{M}+\mathrm{H}]^{+}$863.1878, found 863.1871; IR $\left(\mathrm{CH}_{2} \mathrm{Cl}_{2}\right.$ film): $\tilde{v}=2964$, 2927, 2868, 1676, 1650, 1604, 1577, 1520, 1465, 1425, 1412, 1331, 1296, 1253, $1137,1062,943,803,758,723,705,683 \mathrm{~cm}^{-1}$.

General procedure for Suzuki reaction: Under an argon atmosphere, a preheated Schlenk-flask equipped with a Teflon-coated magnetic stirring bar and septum was charged with the base (3 equiv.). Next, a solution of the boronic acid (1.2 equiv.), aromatic bromide (1 equiv.), and internal standard (1 equiv.) were added followed by a solution of PEPPSI-type catalyst (0.01 equiv.). The mixture was stirred at elevated temperature for a given time. The results were analyzed by means of gas chromatography.

General procedure for Mizoroki-Heck: Under an argon atmosphere, a preheated Schlenk-flask equipped with a Teflon-coated magnetic stirring bar and septum was charged with AcONa (3 equiv.). Next, a solution of styrene (1.2 equiv.), aromatic halide (1 equiv.), and internal standard ( 1 equiv.) were added followed by a solution of PEPPSI-type catalyst ( 0.01 equiv.). The mixture was stirred at elevated temperature for a given time. All volatiles were removed in vacuum and the crude product was purified by column chromatography.

\section{Acknowledgements}

A.K. is grateful to the Homing Plus Programme of the Foundation for Polish Science co-financed by the European Union, Regional Development Fund (HOMING PLUS/2013-7/6). A.P. is a Serra Húnter Fellow and ICREA Academia Prize 2019, and we thank the Spanish MINECO for project PGC2018-097722-B-I00.

\section{Supplementary Material}

Supplementary Material contains: computational details, structural and electronic data from DFT calculations, description of effect of the PEPPSI type ligands on the metal centre and on the NHC ligand (\%VBur), steric maps and $\mathrm{NCl}$ plots, xyz coordinates of all computed species and basic details about X-ray experiments.

\section{References}

1. Shalu, S.; Sonika, J.; Manish, S.; Rajendra, V.; Jaya, D. Curr. Org. Synth. 2019, 16, 1105-1142.

2. Molnár, Á., Palladium-Catalyzed Coupling Reactions: Practical Aspects and Future Developments. WileyVCH: 2013. https://doi.org/10.1002/9783527648283

3. Buskes, M. J.; Blanco, M.-J. Molecules 2020, 25, 3493. 
https://doi.org/10.3390/molecules25153493

4. Organ, M. G.; Chass, G. A.; Fang, D.-C.; Hopkinson, A. C.; Valente, C. Synthesis 2008, 2008, $2776-2797$. https://doi.org/10.1055/s-2008-1067225

5. Valente, C.; Pompeo, M.; Sayah, M.; Organ, M. G. Org. Process Res. Dev. 2014, 18, 180-190. https://doi.org/10.1021/op400278d

6. Froese, R. D. J.; Lombardi, C.; Pompeo, M.; Rucker, R. P.; Organ, M. G. Acc. Chem. Res. 2017, 50, 22442253.

https://doi.org/10.1021/acs.accounts.7b00249

7. O'Brien, C. J.; Kantchev, E. A. B.; Valente, C.; Hadei, N.; Chass, G. A.; Lough, A.; Hopkinson, A. C.; Organ, M. G. Chem. Eur. J. 2006, 12, 4743-4748. https://doi.org/10.1002/chem.200600251

8. Wang, C.-A.; Liu, C.; Szostak, M. Org. Process Res. Dev. 2020, 24, 1043-1051. https://doi.org/10.1021/acs.oprd.0c00054

9. Shi, S.; Lei, P.; Szostak, M. Organometallics 2017, 36, 3784-3789. https://doi.org/10.1021/acs.organomet.7b00565

10. Lei, P.; Meng, G.; Ling, Y.; An, J.; Szostak, M. J. Org. Chem. 2017, 82, 6638-6646. https://doi.org/10.1021/acs.joc.7b00749

11. Organ, M. G.; Çalimsiz, S.; Sayah, M.; Hoi, K. H.; Lough, A. J. Angew. Chem. Int. Ed. 2009, 48, $2383-2387$. https://doi.org/10.1002/anie.200805661

12. Osińska, M.; Gniewek, A.; Trzeciak, A. M. J. Mol. Catal. A: Chem. 2016, 418-419, 9-18. https://doi.org/10.1016/i.molcata.2016.03.022

13. Zhang, Y.; César, V.; Storch, G.; Lugan, N.; Lavigne, G. Angew. Chem. Int. Ed. 2014, 53, 6482-6486. https://doi.org/10.1002/anie.201402301

14. Pompeo, M.; Froese, R. D. J.; Hadei, N.; Organ, M. G. Angew. Chem. Int. Ed. 2012, 51, 11354-11357. https://doi.org/10.1002/anie.201205747

15. Hoi, K. H.; Coggan, J. A.; Organ, M. G. Chem. Eur. J. 2013, 19, 843-845. https://doi.org/10.1002/chem.201203379

16. Kumar, A.; Kumar, M.; Verma, A. K. J. Org. Chem. 2020, 85, 13983-13996. https://doi.org/10.1021/acs.joc.0c02024

17. Song, A. X.; Zeng, X.-X.; Ma, B.-B.; Xu, C.; Liu, F.-S. Organometallics 2020, 39, 3524-3534. https://doi.org/10.1021/acs.organomet.0c00494

18. Kaloğlu, M.; Gürbüz, N.; Yıldırım, i.; Özdemir, N.; Özdemir, İ. Appl. Organomet. Chem. 2020, 34, e5387. https://doi.org/10.1002/aoc.5387

19. Ostrowska, S.; Kubicki, M.; Pietraszuk, C. Inorg. Chim. Acta 2018, 482, 317-323. https://doi.org/10.1016/j.ica.2018.06.028

20. Salazar, C. A.; Flesch, K. N.; Haines, B. E.; Zhou, P. S.; Musaev, D. G.; Stahl, S. S. Science 2020, 370, 14541460.

21. https://www.strem.com/catalog/v/46-0220/51/palladium 649736-75-4.

22. Kajetanowicz, A.; Milewski, M.; Rogińska, J.; Gajda, R.; Woźniak, K. Eur. J. Org. Chem. 2017, 2017, 626638.

https://doi.org/10.1002/ejoc.201601344

23. Hruszkewycz, D. P.; Balcells, D.; Guard, L. M.; Hazari, N.; Tilset, M. J. Am. Chem. Soc. 2014, 136, 73007316. 
24. Zhou, T.; Ma, S.; Nahra, F.; Obled, A. M. C.; Poater, A.; Cavallo, L.; Cazin, C. S. J.; Nolan, S. P.; Szostak, M. iScience 2020, 23, 101377. https://doi.org/10.1016/i.isci.2020.101377

25. Li, G.; Zhou, T.; Poater, A.; Cavallo, L.; Nolan, S. P.; Szostak, M. Catal. Sci. Technol. 2020, 10, 710-716. https://doi.org/10.1039/C9CY02080B

26. Li, G.; Lei, P.; Szostak, M.; Casals-Cruañas, E.; Poater, A.; Cavallo, L.; Nolan, S. P. ChemCatChem 2018, 10, 3096-3106. https://doi.org/10.1002/cctc.201800511

27. Shi, S.; Nolan, S. P.; Szostak, M. Acc. Chem. Res. 2018, 51, 2589-2599. https://doi.org/10.1021/acs.accounts.8b00410

28. Meconi, G. M.; Vummaleti, S. V. C.; Luque-Urrutia, J. A.; Belanzoni, P.; Nolan, S. P.; Jacobsen, H.; Cavallo, L.; Solà, M.; Poater, A. Organometallics 2017, 36, 2088-2095. https://doi.org/10.1021/acs.organomet.7b00114

29. Melvin, P. R.; Nova, A.; Balcells, D.; Dai, W.; Hazari, N.; Hruszkewycz, D. P.; Shah, H. P.; Tudge, M. T. ACS Catal. 2015, 5, 3680-3688. https://doi.org/10.1021/acscatal.5b00878

30. Singh, V. K.; Verma, S. K.; Kadu, R.; Mobin, S. M. RSC Adv. 2015, 5, 43669-43686. https://doi.org/10.1039/C5RA02295A

31. Ciftci, H. I.; Bayrak, N.; Yıldırım, H.; Yıldız, M.; Radwan, M. O.; Otsuka, M.; Fujita, M.; Tuyun, A. F. Arch. Pharm. 2019, 352, 1900170.

https://doi.org/10.1002/ardp.201900170

32. Ware, A. P.; Patil, A.; Khomane, S.; Weyhermüller, T.; Pingale, S. S.; Salunke-Gawali, S. J. Mol. Struct. 2015, 1093, 39-48. https://doi.org/10.1016/i.molstruc.2015.03.016

33. Madhupriya, S.; Elango, K. P. Spectrochim. Acta A 2012, 97, 429-434. https://doi.org/10.1016/i.saa.2012.06.020

34. Sayah, M.; Organ, M. G. Chem. Eur. J. 2013, 19, 16196-16199.

https://doi.org/10.1002/chem.201303756

35. Mayer, I. Chem. Phys. Lett. 1983, 97, 270-274. https://doi.org/10.1016/0009-2614(83)80005-0

36. Mayer, I. Int. J. Quantum Chem. 1984, 26, 151-154. https://doi.org/10.1002/qua.560260111

37. Poater, A.; Vummaleti, S. V. C.; Pump, E.; Cavallo, L. Dalton Trans. 2014, 43, 11216-11220. https://doi.org/10.1039/C4DT00325J

38. Kumar, V.; Chawla, M.; Cavallo, L.; Wani, A. B.; Manhas, A.; Kaur, S.; Poater, A.; Chadar, H.; Upadhyay, N. Inorg. Chim. Acta 2018, 469, 379-386. https://doi.org/10.1016/j.ica.2017.08.064

39. Falivene, L.; Credendino, R.; Poater, A.; Petta, A.; Serra, L.; Oliva, R.; Scarano, V.; Cavallo, L. Organometallics 2016, 35, 2286-2293. https://doi.org/10.1021/acs.organomet.6b00371

40. Falivene, L.; Cao, Z.; Petta, A.; Serra, L.; Poater, A.; Oliva, R.; Scarano, V.; Cavallo, L. Nat. Chem. 2019, 11, 872-879. https://doi.org/10.1038/s41557-019-0319-5 
41. Poater, A.; Cosenza, B.; Correa, A.; Giudice, S.; Ragone, F.; Scarano, V.; Cavallo, L. Eur. J. Inorg. Chem. 2009, 2009, 1759-1766.

https://doi.org/10.1002/ejic.200801160

42. Poater, A. J. Phy. Chem. Lett. 2020, 11, 6262-6265.

https://doi.org/10.1021/acs.jpclett.0c01828

43. Geerlings, P.; De Proft, F.; Langenaeker, W. Chem. Rev. 2003, 103, 1793-1874.

https://doi.org/10.1021/cr990029p

44. Poater, A.; Gallegos Saliner, A.; Solà, M.; Cavallo, L.; Worth, A. P. Expert Opin. Drug Deliv. 2010, 7, 295305.

https://doi.org/10.1517/17425240903508756

45. Parr, R. G.; Szentpály, L. v.; Liu, S. J. Am. Chem. Soc. 1999, 121, 1922-1924.

https://doi.org/10.1021/ja983494x

46. Johnson, E. R.; Keinan, S.; Mori-Sánchez, P.; Contreras-García, J.; Cohen, A. J.; Yang, W. J. Am. Chem. Soc. 2010, 132, 6498-6506.

https://doi.org/10.1021/ja100936w

47. Contreras-García, J.; Johnson, E. R.; Keinan, S.; Chaudret, R.; Piquemal, J.-P.; Beratan, D. N.; Yang, W. J. Chem. Theory Comput. 2011, 7, 625-632.

https://doi.org/10.1021/ct100641a

48. Masdemont, J.; Luque-Urrutia, J. A.; Gimferrer, M.; Milstein, D.; Poater, A. ACS Catal. 2019, 9, $1662-1669$. https://doi.org/10.1021/acscatal.8b04175

49. Poater, J.; Gimferrer, M.; Poater, A. Inorg. Chem. 2018, 57, 6981-6990.

https://doi.org/10.1021/acs.inorgchem.8b00670

50. Ahmadvand, Z.; Bayat, M.; Zolfigol, M. A. J. Comput. Chem. 2020, 41, 2296-2309.

https://doi.org/10.1002/jcc.26393 